\title{
Alternative Friction Stir Welding Technology for Titanium-6Al-4V Propellant Tanks within the Space Industry
}

\author{
W. D. P. Brassington, Dr P. A. Colegrove
}

Welding and Laser Processing Centre, Cranfield University, Cranfield, United Kingdom

\begin{tabular}{|l|l|}
\hline Wayne D. Brassington & Paul A. Colegrove \\
89 Beamhill Road & Building 46 \\
Burton-upon-Trent & Cranfield University \\
DE130AD & Cranfield, Bedfordshire, MK43 0AL \\
United Kingdom & United Kingdom \\
E mail: waynebrasso@hotmail.co.uk & Email: p.colegrove@,cranfield.ac.uk \\
T: $+44(0) 1283569754$ & T: $+44(0) 1234754694$ \\
\hline
\end{tabular}

W. Brassington has 18 years of experience in metallurgical/ laboratory environment working for Rolls-Royce (UK), EADS Astrium (UK), The European Space Agency (Netherlands) and Airbus DS (Germany). His expertise focusses on metallurgy with respect to aerospace alloys and associated manufacturing processes. He is currently studying at Cranfield University for an MSc in Welding Engineering.

Dr. Paul Colegrove gained his first degree in Mechanical Engineering from the University of Adelaide, Australia in 1995. He then worked in the Steel and Mineral Processing Industry for 3 years, before doing a Master of Engineering Science Degree at the University of Adelaide in 1999. In 2001 he commenced a PhD at the University of Cambridge on the Modelling of Friction Stir Welding, which he continued in 2004 as a post doc. Since 2006, Paul has worked at Cranfield University as a lecturer and senior lecturer in Welding Engineering with interests in controlling residual stress and distortion through plastic deformation, Wire + Arc Additive Manufacture; Weld modelling; Modelling of friction-based welding processes; Weld process development. He is also the course director for the Welding Engineering MSc course.

Published by Maney Publishing (T\&F). This is the Author Accepted Manuscript issued with: Creative Commons Attribution Non-Commercial License (CC:BY:NC 4.0).

The final published version (version of record) is available online at DOI:10.1080/13621718.2016.1236002. Please refer to any applicable publisher terms of use. 


\title{
Alternative Friction Stir Welding Technology for Titanium-6Al-4V Propellant Tanks within the Space Industry
}

\author{
W. D. P. Brassington, Dr P. A. Colegrove \\ Department of Welding Engineering, Cranfield University, United Kingdom, 2016
}

\begin{abstract}
Friction Stir Welding offers an appealing solid state joining alternative to traditional fusion welding techniques for titanium alloys because it reduces problems associated with high temperature processing. Propellant tanks are a critical component of every spacecraft and contain several weld seams and a prime candidate for this innovative technology. This paper reviews the current technological maturity of FSW relative to titanium alloys and considers the application with respect to a pressure vessel. FSW is currently in a period of significant investment by large engineering companies and international research institutions. The technology is advancing and evolving to cater for high temperature alloys. Stationary Shoulder FSW and Hybrid techniques show promising potential with respect to Ti-6Al-4V. The tool material and limited process window for this material are restrictive factors at present but can be overcome with future development.
\end{abstract}

\section{Key Words}

Friction Stir Welding, Titanium, Titanium Alloy, Propellant Tank, Propulsion, Space, 


\section{Introduction}

Titanium alloys are a preferred material in the space industry due to the high strength to weight ratio, excellent corrosion resistance and compatibility with most propellants. A common application is for propellant tanks which are used to store fuels during the launch phase, station keeping manoeuvres and interplanetary travel. Pressure vessels are integral on all spacecraft and any failure would result in catastrophic loss of the mission. High strength, stiffness and fracture toughness are key properties for these tanks so forged titanium shells are required. Historically, Electron Beam Welding (EBW) and Gas Tungsten Arc Welding (GTAW) welding have been the optimal joining processes employed.

Friction Stir Welding (FSW) is considered a future technology which could offer benefits in terms of weight savings, improved quality and reduced environmental impact. Mass is critical on Spacecraft with weight savings having a compounding effect on the mass at the launch site. The Ariane 5 ECA has a launch mass of 769 tonnes of which $60 \%$ is in fuel ${ }^{[1]}$. This high cost and ultra-conservative industry also requires superior weld quality where there are no second chances, limited repair options and no in-service inspections like in aerospace. An initiative known as 'Clean Space' also requires industry to embrace new environmentally friendly technology where feasible ${ }^{[2]}$.

The European space industry is notoriously slow to adopt new technology and currently FSW is seldom used with any material types. Several research and development activities have been performed or are in progress but the focus is on high strength aluminium alloys. For FSW to become a competitive welding technology for titanium pressure vessels the rationale for such a development would have to satisfy the cost, quality, mass reduction and environmental requirements. Introducing FSW to established designs would be challenging, alternative designs could be developed that exploit the process' unique characteristics.

\subsection{Scope}

This paper will focus on the advances of FSW in relation to common titanium alloys and explore the potential within the space sector. The study will concentrate on research that has been performed in the past 20 years. The output will identify successes that have been achieved and the limitations that have been encountered and any opportunities that have not been investigated. The competiveness of the more standard welding processes mentioned will also be considered to better understand the limited use of FSW for titanium alloys. The requirements of the European Space Agency (ESA) will be the 
main consideration within this paper but reference to other government agencies (NASA) will also be included where appropriate.

\section{Propellant Tank Design}

The ground life of a spacecraft is fairly benign until it reaches the launch site, which is typically located in aggressive environments (i.e coastal, high humidity, marine). Weldments must be tested for resistance to general corrosion and Stress Corrosion Cracking (SCC) as part of characterisation. The chemical compatibility with the aggressive propellants such as Mono-Methyl Hydrazine (MMH), Nitrogen Tetroxide (NTO) and liquid gases (oxygen and hydrogen) must also be taken into account ${ }^{[1]}$. Fuel and oxidiser propellants for spacecraft are controlled in the range of $0-50^{\circ} \mathrm{C}$ with heaters (ECSSE-ST-35-03). During the launch materials and welds are exposed to cryogenic temperatures. The vessel (welds) will be exposed to static loads, launch vibration, acceleration, shock and gas pressurisation. Ground acceptance testing is mandatory where tanks are vibration tested to flight levels and proof pressure tested. Requirements become even more stringent if the launcher or spacecraft is manned.

The design of propellant tanks is covered in Fortescue et al ${ }^{[1]}$ and ANSI/ AIAA standards ${ }^{[3]}$. The quantity of fuel required to satisfy mission requirements is the main factor which determines the pressure vessels size. The common shape of the tanks are spherical, cylindrical or Cassini configurations (figure 1). Propellant tanks are pressurised by a separate gas source (pressurant tank) which directs the fuel towards the engine or thrusters. In some designs the gas is mixed with the liquid propellant and removed by a Propellant Management Device (PMD) which prevents gas bubbles exiting the tank. An alternative design is referred to as a bladder tank where a flexible polymeric material is inserted near the equatorial region which prevents propellant and gas contact $[\mathbf{1 , 4 , 5 ]}$. 


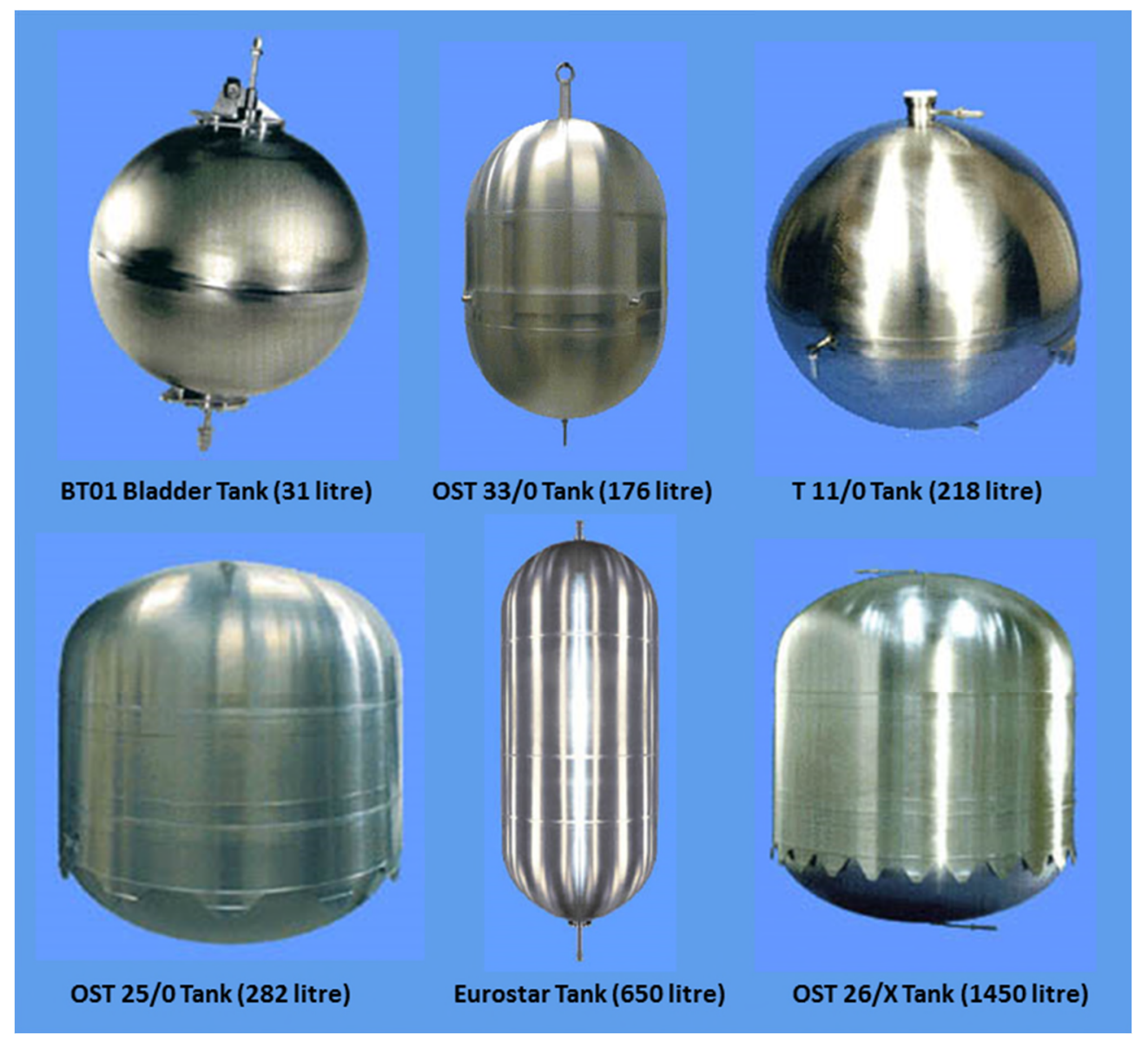

Figure 1 - Examples of different propellant tanks supplied by EADS Astrium GmbH (Bremen). All of the above tanks are made from Titanium 6Al-4V alloy and are joined by EB welding ${ }^{[6]}$.

The spacecraft mounting can be achieved with skirts around the equator or with flanges at the poles. The shell parts of the tank are typically manufactured by a forging process to form hemisphere and cylindrical sections. Subsequent heat treatment is required to remove residual stresses and improve material properties. Solution treated and aged material provides the optimal strength and fracture toughness but annealed material can also be used if sufficient design margins can be demonstrated. Mechanical joints are not permitted so all tanks are fusion welded to achieve structural integrity and leak tightness. The Post Weld Heat Treatments (PWHT) need to consider the size of the vessel and any sensitive parts inside the tank such as non-metallic materials, sensors, vanes and $\mathrm{PMD}^{[4,5]}$.

The joint designs specified are usually butt or ' $\mathrm{J}$ ' preparations (figure 2) with access only possible from the external diameter. Reinforcement can be provided by an internal locking feature which also prevents spatter contamination inside the vessel in the case of EB welding. Additional stiffening is also common with a tapered increase in wall thickness towards the weld joint (figure 2). Some tank designs 
have multiple circumferential welds and several tanks are required per spacecraft and also the launch vehicle so the potential for mass savings with reduced wall thickness becomes compelling.

a) J joint
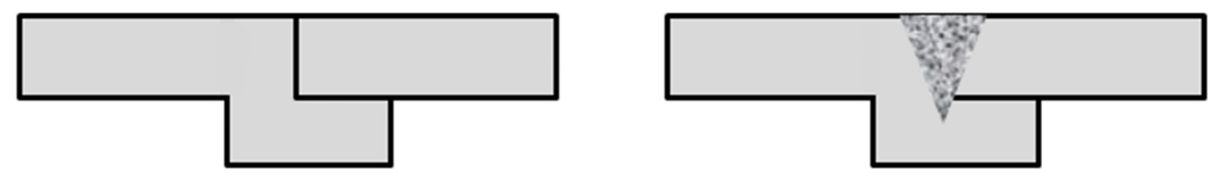

b) Butt joint
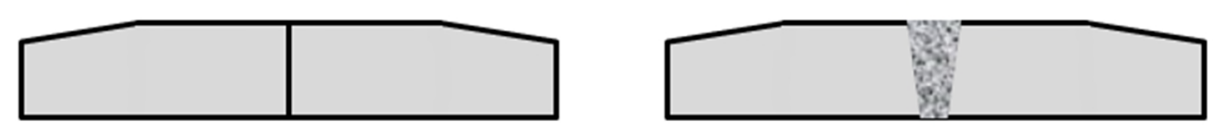

\section{Figure 2 - Examples of joint design used on propellant tanks for circumferential welds. The $J$} type joint (a) is more common for EB welding and Butt joints (b) can be used for GTAW.

All pressure vessels used in space are defined as fracture critical items as per ECSS-E-ST-32-01C (Space Engineering - Fracture Control). Fracture mechanics are applied to ensure that design margins exceed the mission environment with a degree of conservatism. The welds are given particular focus with respect to material properties, geometry and defects. Given defect sizes are used in the fracture assessment depending on the level of Non-Destructive Inspection (NDI) applied. Higher sensitivity NDI processes can be selected which are capable of detecting smaller defects thus increasing safety margins. Ultimately an initial defect size is assumed and the fracture mechanics can determine crack growth rates. The consideration given to weldments is complex as the properties of the parent metal, Heat Affected Zone (HAZ) and weld metal must be known ${ }^{[5]}$.

Propellant tank manufacturing is a very low volume production scenario so the benefits of batch production cannot be applied. Production usually consists of two to four flight units in a batch to fulfil an order for a single spacecraft. Occasionally a constellation of satellites may be required but delivery will be scheduled relative to the launch dates of each spacecraft. In the launcher business, continuous production is possible where for example the Ariane 5 rocket launched almost once every two months in $2014^{[7]}$. 


\subsection{Conventional Welding Techniques}

\subsubsection{Electron Beam Welding}

EBW is the most common method used for circumferential girth welds on propellant tanks. The reduced heat input, narrow welds, superior quality, repeatability and good dimensional control are the driving factors for its selection. However, the capital outlay, set up time and running costs for EBW equipment are substantial and the welding time is prolonged due to the vacuum cycle ${ }^{[8]}$. Figure 3 shows the scale of the EB facility at the EADS Astrium site in Bremen used to weld the Ariane 5 propellant tanks. The capital expenditure was part of a multi-million Euro investment to expand the product range to cater for larger diameter and length pressure vessels. The vacuum environment provides protection for the weld and adjacent areas at elevated temperatures. Consideration must also be given for the radiation produced in the form of X-rays which are a health hazard. EBW is normally an autogeneous method (no filler material) so joint preparation has to be precise ${ }^{[8]}$. The overheads to maintain a facility of this size are substantial.

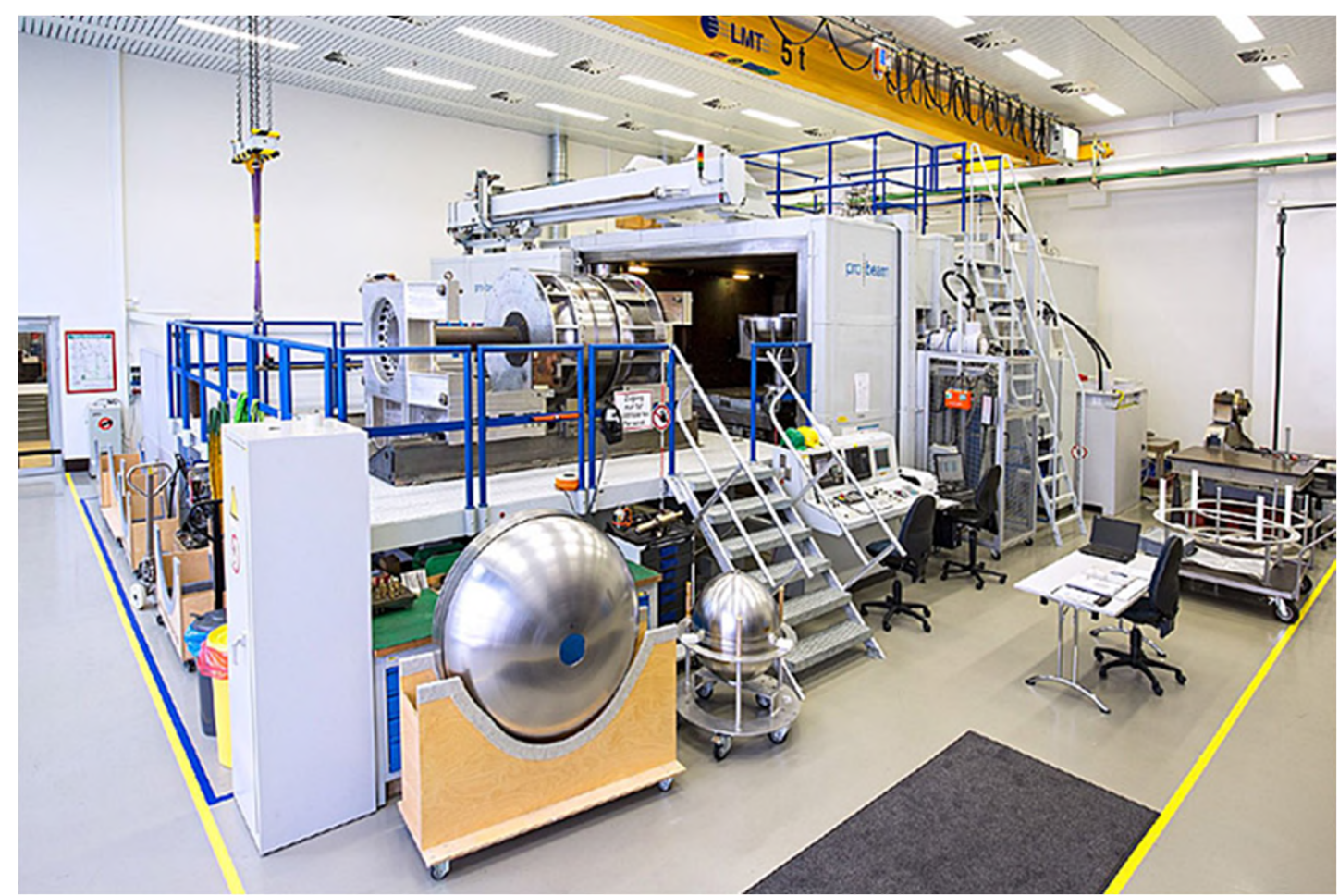

Figure 3 - Steigerwald Electron Beam Welding facility at EADS Astrium GmbH (Bremen) ${ }^{[6]}$.

A common problem with EB welding titanium alloys is porosity which can even occur in a vacuum.

Weld acceptance standards and fracture mechanics can tolerate low levels of porosity. Common Aerospace standards such as AMS 2681 and DIN 29595 allow local porosity around $20 \%-30 \%$ of the 
wall thickness depending on the joint classification. Above these limitations, re-welding of the joint is the normal rework action to remove a pore. During weld qualification a maximum number of re-welds will be determined as repeated thermal cycles will degrade the material properties. Over-welds can cause a large pore to separate into several smaller pores which are less satisfactory from a structural engineering perspective. Porosity is a common cause for scrapping of tank sections and even whole tanks which have a value of 500k - 1000k Euro. The high mission costs and insurance premiums involved in the industry result in a high level of conservatism and a low risk approach is adopted.

\subsubsection{Gas Tungsten Arc Welding}

GTAW welding is not as commonly used for propellant tank manufacture compared to EBW. A rotational device is required and the weld area requires good shielding with high purity (99.999\%) Argon gas as per ISO 14175. For the closure weld of the tank the internal volume will be filled with Argon. The piece parts can be tack welded to simplify the jigging required and also the welds are usually fully penetrating. This can be a benefit over EBW where fully penetrating welds would cause spatter inside the tank ${ }^{[8]}$. The dimensional control when using GTAW is more complicated due to larger weld beads and non-compliances are common against propellant tank length and volume. GTAW offers a cheaper joining solution but cannot compete with the process control, quality and accuracy of EB welding. GTAW is a preferred solution for smaller tank types and spherical designs which only require a single circumferential weld. GTAW of titanium alloys can be prone to excessive grain growth which causes reduced ductility in the weld metal ${ }^{[9]}$. This is not a limiting factor but reduced ductility would also imply lower fracture toughness which is a major consideration for propellant tanks.

\subsection{Non-Destructive Inspection}

Conventional NDI is rarely accepted as the fracture analysis will require detection of smaller defects than can be detected with these techniques to increase design margins. Therefore, high sensitivity NDI processes are required for inspection of propellant tank welds. These methods termed 'special NDI' have to demonstrate the higher sensitivity through a Probability of Detection (POD) study or a Point Estimate Method (PEM) ${ }^{[10]}$. The PEM approach is more cost effective but the POD method is a more robust statistical solution which allows minimal detectable flaw sizes to be established. The POD method requires a large number of specimens with cracks and is specific to a company, the equipment, procedures and operators. The specimens may have to be representative of the production joint but 
exceptions are usually permitted to simplify the verification process. The objective of both methods is to demonstrate a $90 \%$ probability of detection with a $95 \%$ confidence level for given defects sizes using a specified NDI technique. Any new welding process or technology would require complimentary NDI solutions to be qualified that satisfy one of the described methods ${ }^{[11,12]}$.

Due to several tank failures during the Apollo missions, NASA were forced to implement special NDI methods to enhance inspection capabilities to support fracture control ${ }^{[13]}$. New welding processes such as FSW also played a role in the development and adaptation of Eddy current inspection, digital Xrays and Phased Array Ultrasonic Testing (PAUT) to aid the fracture control and life management of $\operatorname{tanks}^{[14]}$.

\section{Friction Stir Welding Overview}

FSW was invented by The Welding Institute (TWI) in the United Kingdom in the early 1990s and protected under UK, European and International patents ${ }^{[15]}$. The process has experienced substantial growth since the 1990s across many industries as can be seen by the amount of licenses granted by the TWI. There was linear growth in the number of licenses issued from nothing in 1994 to almost 200 in $2007^{[16]}$.

The technique was derived from conventional friction welding processes and was envisaged as a solution to joining aluminium alloys that were difficult to weld by arc processes ${ }^{[17]}$. The process involves generating frictional heat through a rotating non-consumable probe and stirring the material below its melting point to form a joint. The basic FSW tooling used is an assembly that consists of a tool, shoulder and pin. The wide bodied tool transfers the forging loads from the machine as shown in figure 4 . The base of the tool has a shoulder arrangement that contacts the joint. The geometry of the shoulder has a slight taper and grooves to aid material transfer. The pin is the first point of contact with the work piece and is plunged to the full weld depth. The pin geometry also has a significant influence on heat transfer ${ }^{[18]}$. The process was quickly identified as being cost effective and relatively simplistic in terms of parameters and their interactions ${ }^{[18]}$. The process is also favourable from a health and safety perspective as there are no fumes or spatter and there is a high level of automation. 


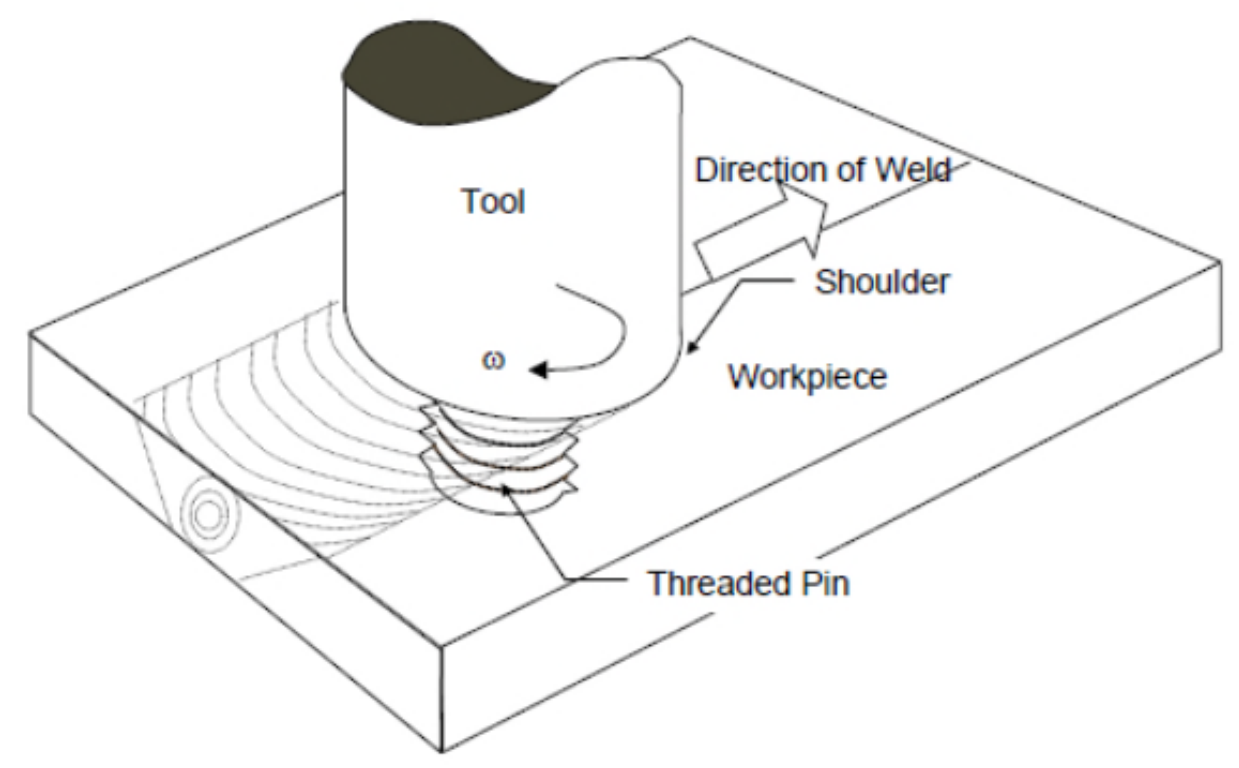

Figure 4 - The basic principal of FSW shown on a butt joint ${ }^{[19]}$.

The major appeal with FSW as a future welding technology is the ability to produce high quality welds with minimal defects. The resulting welds exhibit excellent mechanical properties as it transforms the solid material to a plastic state and then stirs the material under a forging pressure. The forging pressures can be very high so backing plates are used to provide support to the joint. The plunge force is proportional to the surface area of the contact area of the pin on entry. Forces are most significant in the $\mathrm{Z}$ direction (plunge force) but also act in the horizontal axis due to traversing and tool rotation. The resulting weld is not symmetrical as there are different influences from the advancing and retreating side of the pin as shown above. Material is stirred from the advancing side towards the retreating side and fills the gap left by the tool as it traverses ${ }^{[20]}$.

Typically the process is performed around $0.7 \mathrm{Tm}$ (70\% of the materials absolute melting point) although some literature suggests that $0.6-0.8 \mathrm{Tm}$ is the operational window for the process ${ }^{[\mathbf{2 1}]}$. This solid state process therefore is not susceptible to some of the common defects that occur in welding such as solidification cracking, gas porosity and oxidation. The lower heat input also results in reduced distortion and residual stresses. The welds should also be less sensitive to corrosion and stress corrosion. The process is also fully mechanised so robust and repeatable ${ }^{[18]}$. A dedicated study was performed by Edwards and Ramulu ${ }^{[22]}$ to investigate the peak temperatures of Ti 6Al-4V alloy during FSW. It was concluded that the maximum temperatures were above $1100^{\circ} \mathrm{C}$ but with lower rotational speeds, the temperature could be reduced to below the $\beta$ transus. Spindle speed was identified as the 
dominant parameter in relation to peak temperature ${ }^{[22]}$. The highest temperatures are towards the top of the weld where there is contact with the rotating shoulder.

\subsection{Challenges}

Recently there has been a concentrated effort to apply FSW for higher temperature materials which have much higher melting temperatures than aluminium (see appendix). There are a large number of publications available related to titanium and titanium alloys. With respect to titanium alloys the focus is on tool development and parameter optimisation with the objective to improve tool service life ${ }^{[23]}$. Heat generated at the tool is not conducted away due to titanium having a low thermal conductivity. For FSW, the weldability of titanium alloys is less than that of aluminium alloys and the process/ parameter window is relatively narrow ${ }^{[21]}$.

There are also some challenging aspects to consider for FSW especially related to circumferential welding of pressure vessels. Similar to EBW the process is termed as a 'key hole' process so the method of starting and ending of the welding cycle need to be considered. The common approach is to use run-on and run-off tabs to enter and extract the tool from the work piece. Other solutions are less established but a FSW tool with a retractable pin or additional processing are options ${ }^{[18]}$. The final closure welds on tanks will also present problems as no backing would be possible due to limited access. Additional finishing to make the end of the weld cosmetically acceptable may be required.

\subsection{Status of FSW in the Space Industry}

FSW has not become an established process within the European space industry despite a lot of interest in the research and development activity. The main area of interest has been in relation to high strength aluminium alloys with particular focus on aluminium-lithium systems. However, there is a current 1.2 million Euro GSTP (General Support Technology Programme) research package to investigate FSW of titanium titled: "Manufacturing of Large Friction Stir Welded Structures for Satellite and Launcher Applications" (GSTP ref. G61A-015MS). The Project duration is 18 months scheduled for completion in 2017. The following is a summary of its objective; "ESA has started a GSTP activity which is focused on developing a low cost titanium propellant tank, using Friction Stir Welding. The focus of the Titanium GSTP activity is on the development of the friction stir welding process for titanium alloys which is not as mature as for aluminium, and also addresses the design and manufacturing of 
such a tank (including e.g. fixtures and jigging) ${ }^{[24]}$." The activity is a collaboration between ESA, TWI and Airbus UK and will focus on Ti 15-3-3-3 (15\% V, 3\% Cr, 3\% Al, 3\% Sn) and Ti 6Al-4V alloys. ESA currently considers FSW technology in relation to titanium alloys as being at Technology Readiness Level (TRL) 3 and this programme will aim to raise the maturity to level $6^{[25]}$.

In contrast to the European progress, NASA started developing FSW as a process in the 1990s at the Marshall Space Flight Centre (MSFC). The process was progressed rapidly to an advanced technology readiness level for aluminium alloy structures. By 2006 the process had been used on the Space Shuttle external tanks (Al-Li alloy) and also proposed at the time for the then new Crew Launch Vehicle (CLV). The majority of the early research and development concentrated on aluminium alloys (2000, 6000 and 7000 series $)^{[14]}$. Boeing successfully developed FSW aluminium fuel tanks on the Delta II and Delta IV rockets in the late 1990s. A combined 3300 metres of FSW welds were used on these projects up until 2001. Significant cost savings, improved mechanical properties and reduced cycle times were also claimed in comparison to more traditional welding methods. Space Exploration Technologies Corporation (SpaceX) has qualified FSW for the Aluminium-Lithium alloy (AA 2198) for tanks on the Falcon 9 launcher ${ }^{[18]}$. In a recent article presented at the $50^{\text {th }}$ Jet Propulsion conference, it is stated that FSW will be the baseline joining technique for the F-1 advanced boosters (AA 2219) on the Space Launch System (SLS) rocket ${ }^{[26]}$. Due to the security classifications at NASA it is difficult to access current information regarding the evolution and trends with FSW.

\subsection{Process Economics}

Limited information has been published regarding the economic benefits of FSW especially for titanium alloys. The cost benefits in comparison to other welding methods are an important factor. The main considerations for the economic justification are processing costs, capital expenditure, scale of production and output quality ${ }^{[18]}$.

FSW is a mechanised process and can be completed in a single pass and the production costs can be less than traditional arc processes in terms of labour and time. As FSW is a solid state process the energy input is lower than most fusion welding processes. FSW uses less energy than MIG welding but is not as efficient as laser welding when applied to aluminium alloys ${ }^{[27]}$. The production costs for titanium will be higher than aluminium due to the expensive tool materials required. The production 
costs are also more competitive when comparing with EBW due to the long vacuum cycle. In addition, FSW often requires fewer passes. Edwards et al ${ }^{[28]}$ reported that FSW Ti 6Al-4V joints of $25 \mathrm{~mm}$ thickness could be welded with a single pass where the equivalent EBW joint required 4 passes (2 from each side including cosmetic welds).

In the past the TWI patents (1991 and 1995) required licensing of the process to be granted by the TWI but the cost of such application are not publicised. This would have been additional expense compared to other welding processes but these patents have now expired.

Capital investment required is quite high for the FSW equipment, including fixtures and tooling when compared to arc welding methods. The high forging loads typically require very robust machine fixtures and tooling. FSW would not be competitive with an automated TIG welding set-up if other factors are excluded. However, the expense would still be significantly less than the purchase and installation of an EBW facility on the scale necessary for propellant tanks (see figure 3). Production volume will be very low for most manufacturers of propellant tanks. The economic rationale for investing in FSW machine would be difficult for tank products alone so other applications may need to be sought.

The relatively low frequency of defects and thus repairs required are another positive attribute. Where high levels of integrity and safety are of primary concern FSW offers an attractive solution where cost may not be a driving factor. However, where defects and failures can be tolerated with negligible impact on performance and down time FSW will struggle to be competitive with conventional welding processes on $\operatorname{cost}^{[27]}$.

\section{Friction Stir Welding Process}

\subsection{Tool Design}

Various pin geometries have been proven in the process but tapered, cylindrical or triangular sections with a thread arrangement are the most common. Basic cylindrical shapes are sufficient for thin plate material in aluminium alloys but more complex profiles are required above $12 \mathrm{~mm}$ thickness. TWI Whorl $^{\mathrm{TM}}$ and MX Triflute ${ }^{\mathrm{TM}}$ pins have been designed for deep penetrating welds in aluminium ${ }^{\text {[29] }}$. 
For thin titanium sections the simplistic profiles are preferred as any features would rapidly wear and tool life is a limiting factor. For this reason there is much less mixing when welding titanium alloys compared to aluminium ${ }^{[30]}$. Reducing the forging loads will be necessary to apply FSW to thin walled titanium pressure vessels. Smaller contact areas for example on conical pins reduce forging pressures on weld start up during the plunging stage ${ }^{[29]}$.

The main characteristics required for tool materials for the pin are:-

- Good wear resistance and durability under compressive loads.

- High strength, creep strength and fracture toughness at elevated temperatures.

- Stability in terms of crystallography, chemistry and geometry at high temperature.

- High thermal conductivity for energy transfer.

- Machinability.

The joining of high temperature materials induces high stresses and temperatures on the pin which requires more advanced tooling materials. High strength tool materials need to be able to withstand temperatures of $800-1200^{\circ} \mathrm{C}$ for titanium alloys ${ }^{[9]}$. Refractory materials, Carbides and Nitrides with good high temperature strength that can withstand the process forging loads are necessary. Tungsten Carbide (WC), Tungsten-Tantalum (Ta), Tungsten-Rhenium (Re) and Tungsten-Lanthanum (La) tool materials have been the focus of research for titanium alloys. Elements such as Ta, Re and La are very rare and therefore also expensive. Polycrystalline cubic Boron Nitride $(\mathrm{pcBN})$ tools are also being developed and trialled for high strength materials such as Titanium. These will be evaluated in the following sections.

\subsubsection{Refractory Alloys}

Tungsten based tools have been the concentration of research and development for titanium alloys. There are many documented successes in the use of tungsten based materials with tool life of hundreds of feet. Thompson ${ }^{[31]}$ states that tungsten-lanthanum (1\%) pins have produced acceptable welds in $25 \mathrm{~mm}$ sections in Ti $6 \mathrm{Al}-4 \mathrm{~V}$ alloy with a single pass. It is understood that with increased weld depth, tool degradation is more excessive but successes in such thick sections show the potential of the FSW process for thin walled propellant tanks which are typically below $3 \mathrm{~mm}$. 
In a series of studies by Edwards and Ramulu ${ }^{[22,30,32,33]}, \mathrm{W}-\mathrm{La}$ tapered tools were proven to produce satisfactory welds in Ti 6Al-4V alloys once optimal spindle and traverse speeds were established. The plate thickness varied from $3-12 \mathrm{~mm}$ and under certain conditions minimal tool wear was observed. The purposes of these trails were not to demonstrate tool life but to understand parameter relationships and operating temperatures.

Tungsten Rhenium tools have been popular in experimental studies with Ti 6Al-4V. Buffa et al ${ }^{[34]}$ proved far superior tool life of W $(75 \%)$ - Re $(25 \%)$ tools compared to WC-Co when used in the same conditions on Ti $6 \mathrm{Al}-4 \mathrm{~V}, 3 \mathrm{~mm}$ plate. The W-Re tools completed $19-28$ meters of weld before experiencing excessive wear. The WC-Co (K10-K30 tool) could only achieve half the life in the same conditions and was more susceptible to failure. In another comparative study by Thompson ${ }^{[35]}$, a new tungsten based tool material consisting 20\% Re and 10\% Hafnium Carbide (HfC) was assessed against more established W-La and W- Re pins. The W-Re-HfC performed better in identical conditions in terms of reduced tool wear and microstructural deformation. It was observed that the introduction of HfC prevented excessive grain deformation which is the main degradation mechanism in W-La and $\mathrm{W}-\mathrm{Re}$ pins. As the HfC particles were present at grain boundaries some intergranular cracking was apparent. An evolution of this tool material was then developed by reducing the Re and HfC content to reduce cost and susceptibility to intergranular cracking respectively. The $\mathrm{W}(91 \%), \operatorname{Re}(5 \%)$ and HfC (4\%) tool proved unsuccessful with $6.35 \mathrm{~mm}$ Ti $6 \mathrm{Al}-4 \mathrm{~V}$ due to tool fractures and adhesive wear ${ }^{[36]}$.

\subsubsection{Ceramic Materials}

$\mathrm{PcBN}$ is very hard, durable, stable at high temperatures and has an added benefit that it produces very smooth weld profiles due to its low coefficient of friction. As the plunge depth increases the tendency for tool failure also rises as pcBN has low fracture toughness. The tools are manufactured in the hexagonal form of BN and then sintered to obtain the optimal properties in the cubic structure. The high hardness in the cubic form limits the grinding options available to extend pin life. The material and manufacturing costs are very high so it is limited to specialist applications ${ }^{[37]}$. Zhang et al ${ }^{[38]}$ performed research in pcBN tools on $3 \mathrm{~mm}$ thick commercially pure titanium and found large increases in the weld hardness due to tool debris and the formation of titanium borides. Although not concluded in the article it is a fair assumption that this would have a negative influence on fracture toughness. 


\subsubsection{Tool Shoulder}

In traditional FSW the shoulder rotates and can have a concave or convex geometry. The shoulder induces frictional heat and helps to plasticise the material at the surface of the weld. Additional features can be produced on the shoulder to aid material flow. Due to the low thermal conductivity of titanium the tool temperature has to be managed as it can easily overheat. This can be done through shoulder design or with static shoulder tools thus reducing frictional heat input ${ }^{[18]}$. Water cooling is often employed within the tool to protect the internal features like bearings. Where the materials have low thermal conductivity the impact on weld quality is minimal ${ }^{[34]}$. For aluminium alloys the shoulder and pin can be a made from one piece but for high temperature applications they are separate components. Shoulder materials usually consist of Inconel alloys, $\mathrm{SiC}, \mathrm{Si}_{3} \mathrm{~N}_{4}$ or Tungsten based materials. The shoulder material details are rarely reported in published literature.

\subsection{Parameters}

Tool pitch is a key parameter which consists of the relationship between the rotational speed and the traverse speed. From a simplistic perspective, as the melting point of a given material increases the tool pitch should be reduced to increase heat input ${ }^{[39]}$. For Ti $6 \mathrm{Al}-4 \mathrm{~V}$ alloy in $5 \mathrm{~mm}$ thick butt joints a processing window was presented by Edwards and Ramulu to show the influence of spindle speed and feed rate which is shown in figure $5^{[33]}$. The process window for titanium alloys is narrower than for aluminium alloys ${ }^{[20]}$.

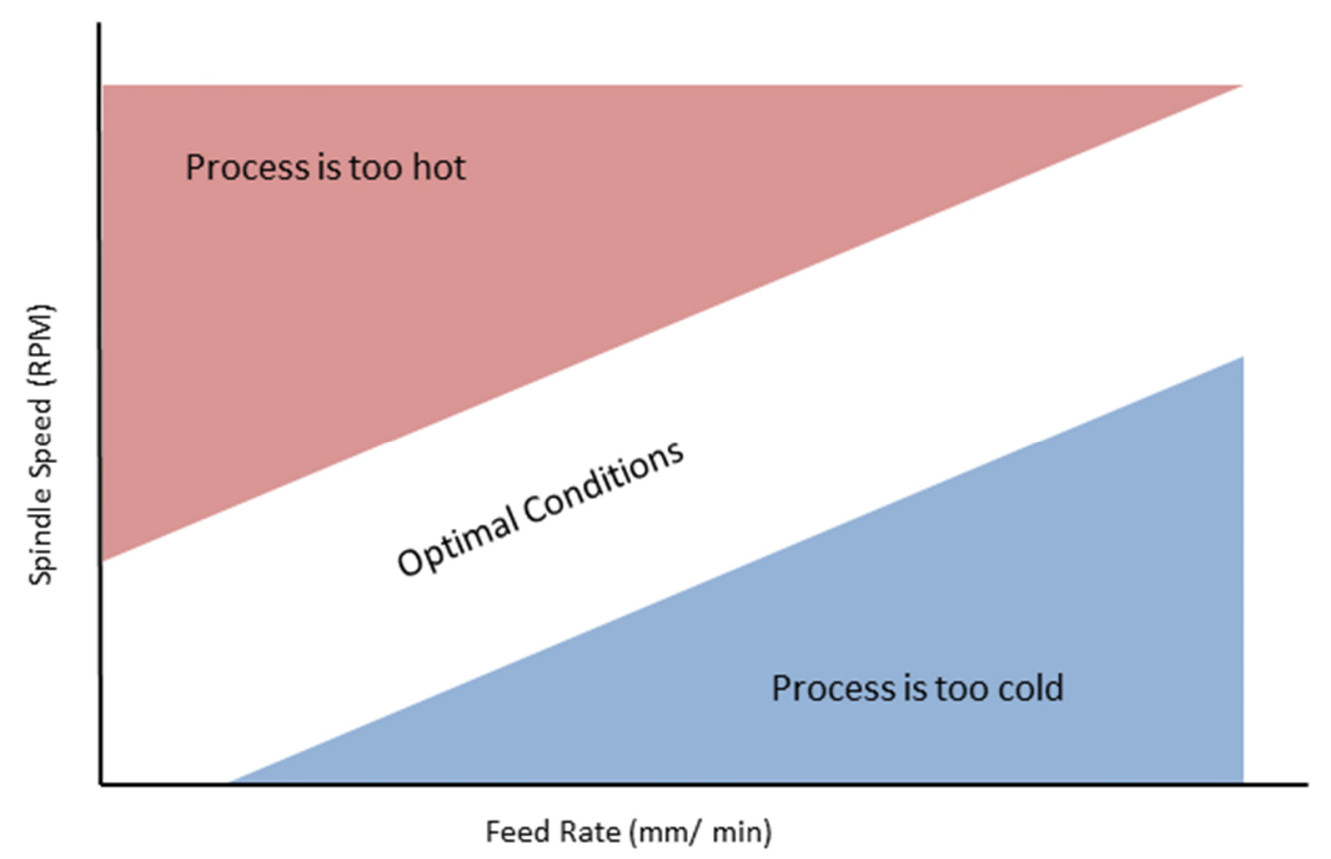


Figure 5 - A simplified illustration of the process window proposed by Edwards and Ramulu ${ }^{[33]}$ for $5 \mathrm{~mm}$ butt joints of Ti 6Al-4V alloy using W-La pins

High rotational speeds and low traverse rates tend to overheat the material. When operating towards the hot side of the process window the forging loads are reduced which in turn reduces the flow stresses leaving the weld susceptible to volumetric defects. Where the feed rate is too high and the spindle speed too low, the process will be too cold to produce acceptable welds. The forging loads can reach critical levels and cause severe tool damage or the machine to abort the weld ${ }^{[33]}$. Edwards and Ramulu $^{[22]}$ also showed the relationship between spindle speed, travel loads and torque loads. Travel and torque loads also decrease as spindle speed is increased. In the same study Edwards and Ramulu ${ }^{[22]}$ presented the forging loads on Ti $6 \mathrm{Al}-4 \mathrm{~V} 12 \mathrm{~mm}$ plate with a $6 \mathrm{~mm}$ tapered pin. The vertical loads ranged from $10 \mathrm{kN}$ to $48 \mathrm{kN}$ across various parameter sets (figure 6). The travel and torque forces were much more benign. In thin plate $(<5 \mathrm{~mm})$ the forging loads are less and usually peak between the plunging stage and the start of traversing. In $1.25 \mathrm{~mm}$ Ti $6 \mathrm{Al}-4 \mathrm{~V}$ plate Buhl et al ${ }^{[9]}$ reported forging loads below $4 \mathrm{kN}$. It is possible to reduce the loads during plunging by drilling a pilot hole at the weld start position.

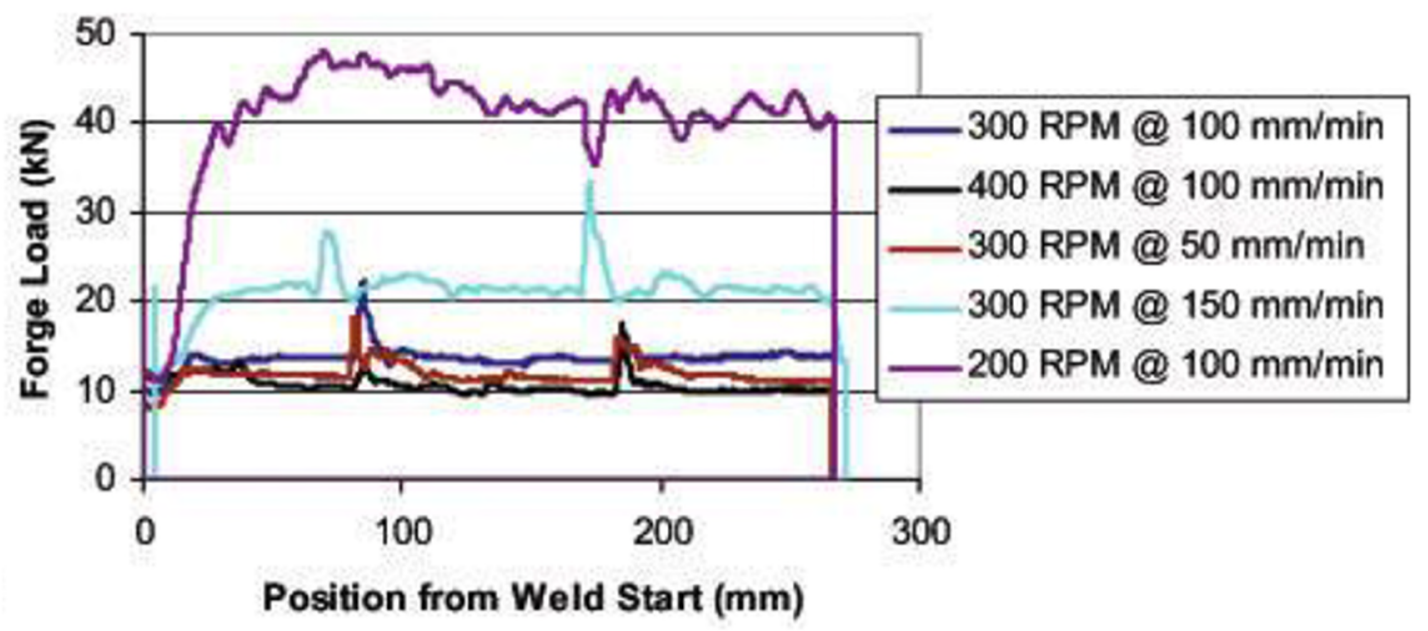

Figure 6 - Forging loads measured in $12 \mathrm{~mm}$ Ti $6 \mathrm{Al}-4 \mathrm{~V}$ plate with a plunge depth of $6 \mathrm{~mm}{ }^{[22]}$.

Edwards and Ramulu showed that travel and rotational speeds had minimal influence on mixing of the $6 \mathrm{~mm}$ Ti $6 \mathrm{Al}-4 \mathrm{~V}$ weld joints ${ }^{[30]}$. This was demonstrated by introducing $\mathrm{W}$-Re powder into the joint prior to welding and using it as a tracer to determine material flow. The subsequent welds were examined using digital X-ray and CT scans in conjunction with metallurgical examination. The level of mixing is more dependent on the materials origin (advancing/ retreating side) within the weld than processing parameters. 
A tilt angle is applied to the tool to improve material flow and increase the forging action of the shoulder after the pin has passed through. This also improves material flow around the pin and shoulder of the tool. The angle is usually between $0^{\circ}$ and $4^{\circ}$ from perpendicular to the welded surface. The relationship between tilt angles and traverse speed has to be considered as the tool could have a tendency to lift from the work piece ${ }^{[40]}$.

Backing plates underneath the tool are common when FSW in the conventional way. To avoid fusion the plates are made from materials that are metallurgically incompatible with the joint. For circumferential welding of propellant tanks the possibility of welding without backing plates would need to be explored, especially for the final tank closure weld. Modern FSW machines have position and force control sensors to provide feedback and make automatic adjustments ${ }^{[40]}$. Just as in arc welding, the FSW parameters combine to give a heat input per $\mathrm{mm}$ of weld. It is possible to demonstrate very different parameter sets which give the same heat input and result in identical microstructures.

\subsection{Titanium Weld Metallurgy}

Ti $6 \mathrm{Al}-4 \mathrm{~V}$ alloy is the workhorse of the aerospace and space industry due to its low density, high strength and fracture toughness. Ti $6 \mathrm{Al}-4 \mathrm{~V}$ accounts for $50 \%$ of use of all the titanium alloys in industry ${ }^{[41]}$. The $\beta$ transus in Ti $6 \mathrm{Al}-4 \mathrm{~V}$ is higher than in its pure form at around $995^{\circ} \mathrm{C}^{[42]}$. During fusion welding processes the material is locally heated to the $\mathrm{BCC}$ ( $\beta$ phase) area of the phase diagram and then cools to the HCP ( $\alpha$ phase) region. During slow cooling weld metal forms a crystal structure known as Widmanstätten (basket weave) consisting of $\beta$ phase sandwiched within $\alpha$ plates (discs). As the weld cools further towards the $\beta$ transus grain boundary $\alpha$ forms ${ }^{[43]}$. The appearance can vary considerably due to the cooling rate which is determined by the heat input of the process and joint section. In EBW, the rapid cooling of the weld metal will form a small $\alpha$ colonies and fine laths which have high strength and low ductility ${ }^{[43]}$. GTAW welds on the other hand produce larger weld beads and hence a slower cooling rate so the lamellar structure will be coarser and contain larger alpha colonies with higher ductility ${ }^{[42]}$. FSW does not exhibit the same high temperatures as fusion welding although recrystallization can occur. 
The main challenges related to FSW of titanium alloys are due the high melting point and low thermal conductivity of the material. For comparison Aluminium alloy AA 7075 (T6) has a melting point at $475^{\circ} \mathrm{C}-635^{\circ} \mathrm{C}$ and thermal conductivity of $130 \mathrm{~W} / \mathrm{m}-\mathrm{K}^{[44]}$. Ti $6 \mathrm{Al}-4 \mathrm{~V}$ alloy melts above $1600^{\circ} \mathrm{C}$ and the thermal conductivity is $6.7 \mathrm{~W} / \mathrm{m}-\mathrm{K}$ at room temperature ${ }^{[41]}$. The higher temperatures to achieve a plastic state adequate for FSW therefore require different tooling to be employed. Titanium also has a strong affinity for interstitial gases (oxygen, hydrogen and nitrogen) at elevated temperatures which cause embrittlement. Therefore, during high temperature processes the surface needs to be protected from diffusion of these elements ${ }^{[42]}$.

\subsubsection{FSW Microstructure}

The weld and adjacent areas produced by FSW are expressed as the Stir Zone (SZ), ThermoMechanically Affected Zone (TMAZ) and Heat Affected Zone (HAZ). The weld metal and HAZ are common features associated with fusion welds. The SZ is the centre of the weld that is produced in the wake of the pin. The HAZ in FSW is typically very thin in comparison to fusion processes due to the low thermal conductivity of titanium and low temperatures involved with FSW. No plastic strain occurs in the HAZ so the resulting microstructure is due to the temperature exposure. The TMAZ is a relatively new term specific to FSW that describes the region between the SZ and HAZ which consists of deformed grains. The TMAZ in titanium welds is not as easily distinguished as it is with aluminium alloys. It is also important to identify the advancing and retreating side of the weld which is relative to tool motion when presenting micrographs of transverse cross sections. Different metallurgical features and defects can be present on each side of the weld ${ }^{[45]}$. Figure 7 provides an overview of a typical FSW weld with associated zones.

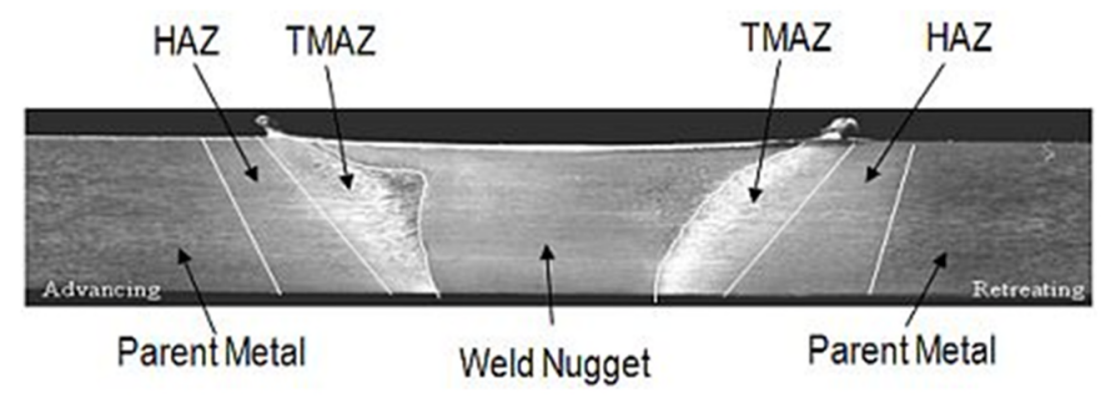

Figure 7 - Transverse cross section to illustrate the weld regions used in FSW ${ }^{[46]}$.

The microstructure and level of deformation can vary depending on whether the weld has been produced above or below the $\beta$ transus. When the process is performed below the $\beta$ transus a fine bi- 
model structure is produced with $\alpha$ grains with the $\beta$ grain boundaries. If processing is done above the $\beta$ transus a lamellar (Widmanstätten) structure is present in the SZ. The resulting microstructure can vary significantly depending on the material form (cast, plate, forged etc) and the heat treatment condition (solution treated and quenched, annealed, aged). Zhang et al ${ }^{[47]}$ concluded that prior $\beta$ and $\alpha$ colony size increases with rotational speed if feed rate is kept constant (figure 8).
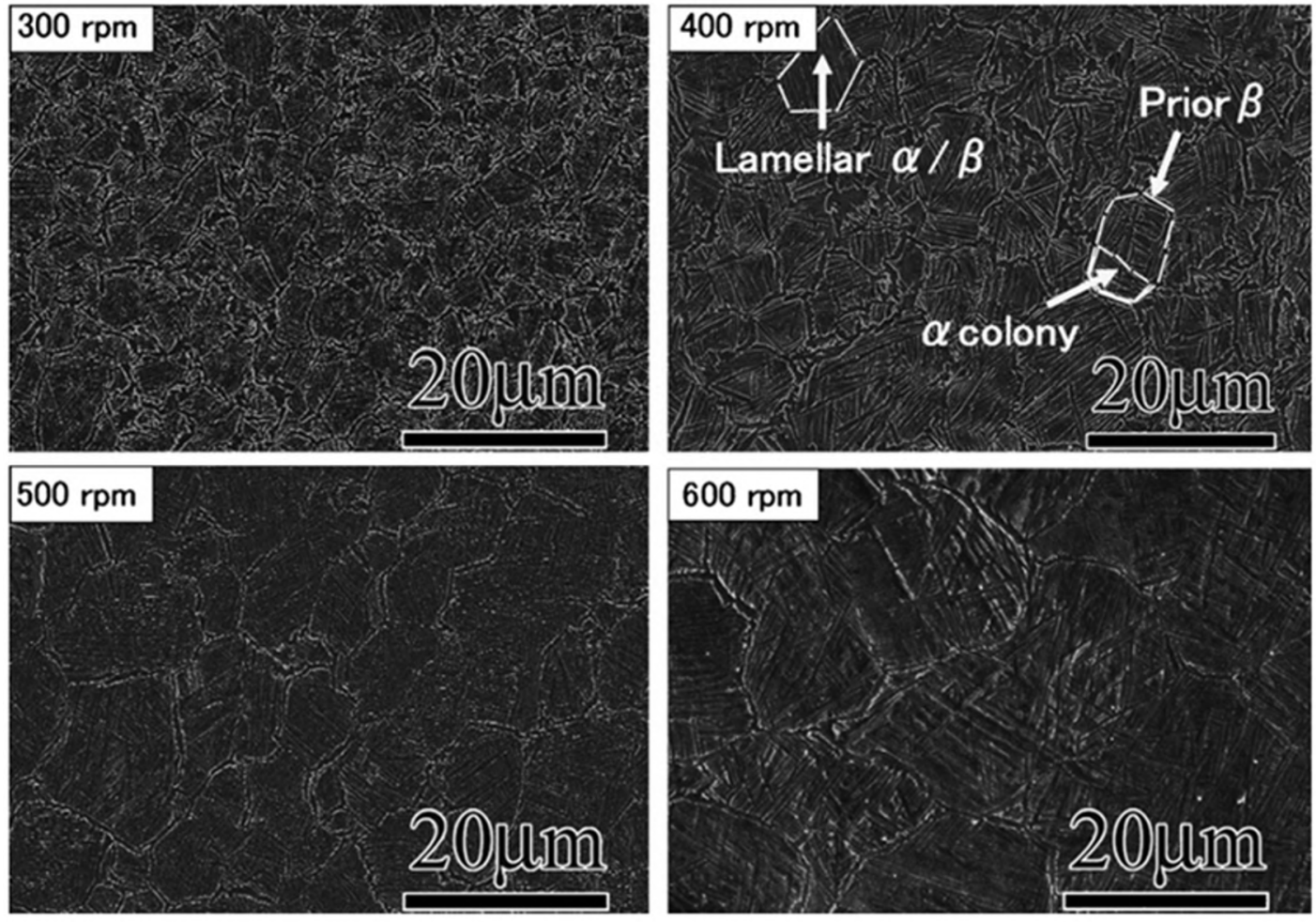

Figure 8 - Scanning Electron Microscope (SEM) images of Ti 6Al-4V alloy Stir Zones at 300 rpm, $400 \mathrm{rpm}, 500 \mathrm{rpm}$ and $600 \mathrm{rpm}$ reported by Zhang et al ${ }^{[47]}$.

Kitamura et al ${ }^{[\mathbf{4 8}]}$ investigated the relationship between the thermal cycle of FSW and the resultant microstructure of Ti $6 \mathrm{Al}-4 \mathrm{~V}$ material on $2 \mathrm{~mm}$ butt joints. Faster cooling rates from above the $\beta$ transus produced higher strength joints due to a fine lamellar microstructure. When welding titanium alloys it is possible to produce a brittle martensite $\left(\alpha^{\prime}\right)$ phase if the cooling rate is too rapid ${ }^{[41]}$. Esmaily et al ${ }^{[49]}$ produced microstructures with small amounts of $\alpha^{\prime}$ when cooling rates of above $410{ }^{\circ} \mathrm{C} / \mathrm{s}^{-1}$. Between $20^{\circ} \mathrm{C} / \mathrm{s}^{-1}$ and $410^{\circ} \mathrm{C} / \mathrm{s}^{-1}$ a mixed microstructure with lamellar was apparent. For comparison, GTAW samples with much slower cooling rates were assessed and no $\alpha$ ' was detected.

Kitamura et al ${ }^{[48]}$ also proposed that the deformation process of FSW actually lowers the $\beta$ transus temperature as the maximum weld temperatures measured in this study were $954^{\circ} \mathrm{C}$, yet $\alpha-\beta$ lamellar were observed in the microstructure. In a similar joint, Zhou et al ${ }^{[50]}$ found that at $500 \mathrm{rpm}$ and above, processing was above the $\beta$ transus producing a prior $\beta$ structure with grain boundary $\alpha$ and 
Widmanstätten lamellar but at $400 \mathrm{rpm}$ there was a transition to equiaxed $\alpha$ and transformed $\beta$. Figure 9 gives a basic indication of how the peak temperature and cooling rate influences the microstructure.

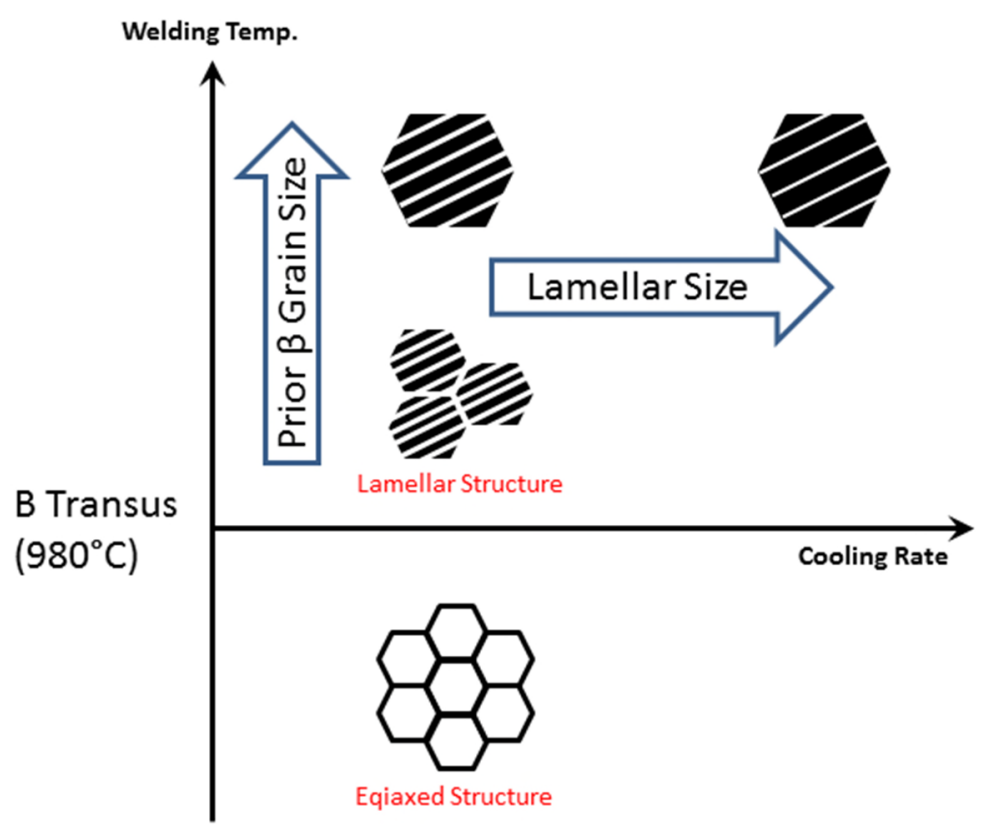

Figure 9 - Microstructure of $\mathrm{Ti} 6 \mathrm{Al}-4 \mathrm{~V}$ dependent on cooling rate and processing relative to the $\beta$ transus as proposed by Kitamura et al ${ }^{[48]}$.

Edwards and Ramulu concluded that SZ grain size increases with joint thickness as shown in figure $10^{[22]}$. Processing below the $\beta$ transus is possible with thin sheet and will tend to form a fine grained equiaxed microstructure due to re-crystallisation. As the section increases so does the energy input and operating temperature of the process so the $\mathrm{SZ}$ will be above the $\beta$ transus ${ }^{[32]}$.

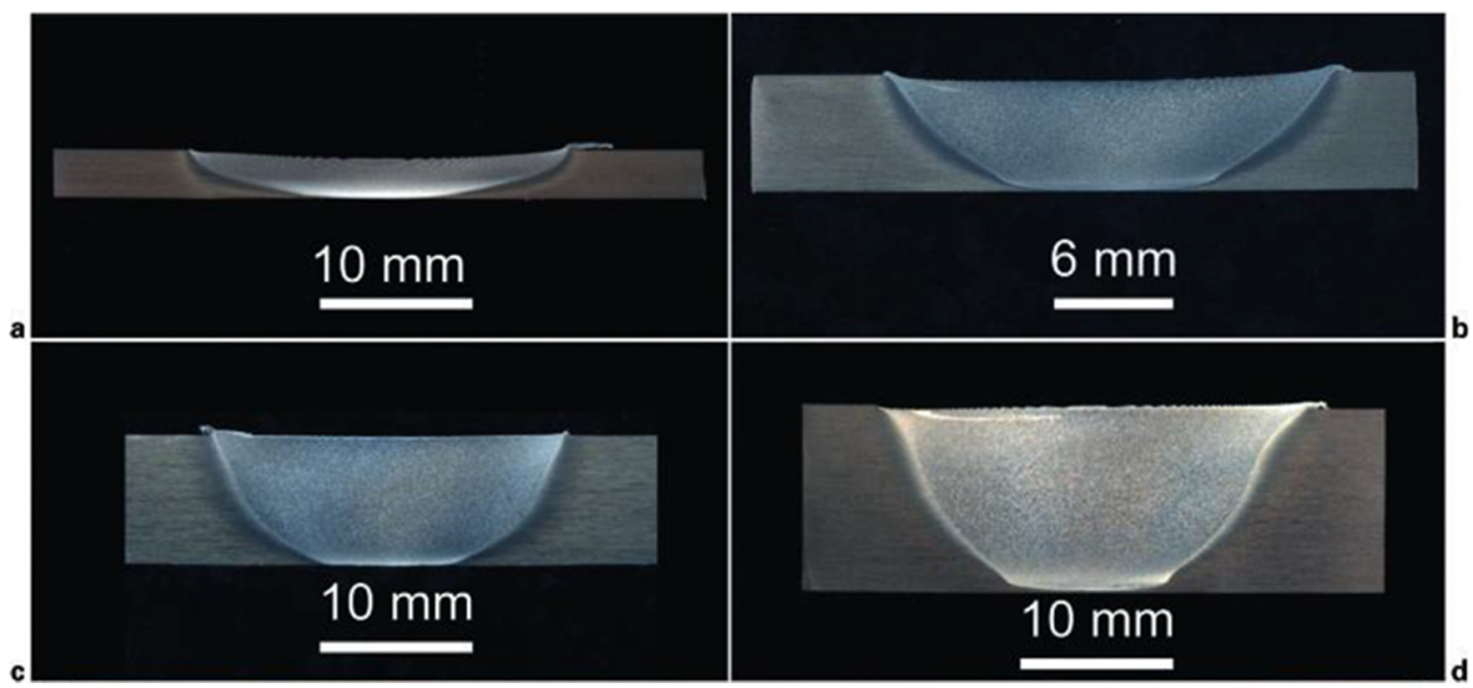

Figure 10 - Transverse micro-sections presented by Edwards and Ramulu ${ }^{[32]}$. Acceptable weld profiles produced for Ti $6 \mathrm{Al}-4 \mathrm{~V}$ alloy in $3 \mathrm{~mm}(\mathrm{a}), 6 \mathrm{~mm}$ (b), $9 \mathrm{~mm}$ (c) and $12 \mathrm{~mm}$ (d) plate. 
The grain direction from the plate is still evident and very small TMAZ and HAZ were observed. Edwards and Ramulu also recognised that the grain structure was uniform across the joint but grain size increased with joint thickness [32]. In a subsequent study Edwards and Ramulu ${ }^{[22]}$ also demonstrated the influence of spindle speed on grain size which is logical given that it is the predominant parameter affecting processing temperature. As the rotation of the tool is increased so does the process temperature.

\subsection{Tensile Strength and Hardness}

The relationship between spindle speed, traverse speed and process temperature was discussed in sections 4.2 and 4.3. It is logical that the process temperature therefore also impacts the mechanical properties of the weld region. Kitamura et $\mathrm{al}^{[48]}$ and Zhou et al ${ }^{[50]}$ documented the influence of spindle speed on the mechanical properties of $2 \mathrm{~mm}$ Ti $6 \mathrm{Al}-4 \mathrm{~V}$ material in the annealed condition as shown in figure 11. It was concluded that incremental increases in spindle speed have caused a reduction in material strength and hardness. It should be noted that even at $600 \mathrm{rpm}$ the tensile properties are still acceptable to AMS 4911 ${ }^{[50]}$. The softening of the SZ will be due to a slow cooling rate as the traverse speed was $75 \mathrm{~mm} / \mathrm{min}$.
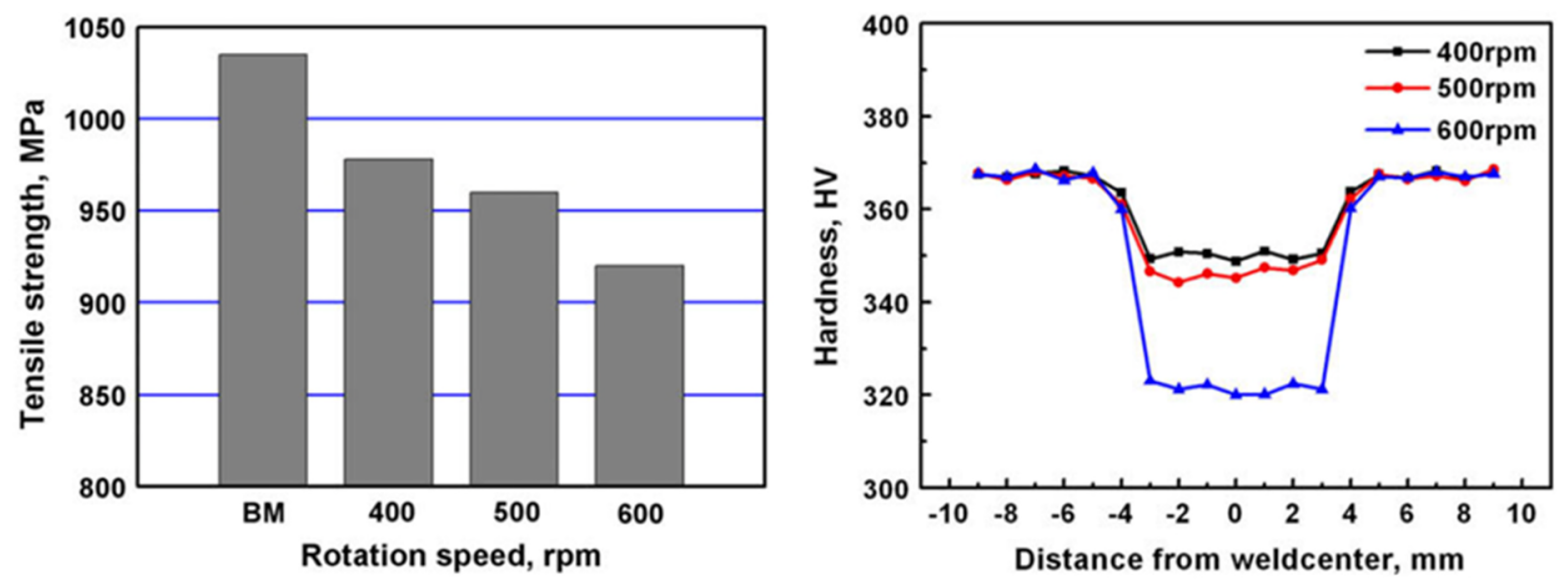

Figure 11 - The influence of spindle speed on tensile strength (left) and hardness across the SZ and HAZ (right) was presented by Zhou et al ${ }^{[50]}$ on $2 \mathrm{~mm}$ thickness Ti 6Al-4V alloy with constant traverse speed.

It is apparent from these two studies that weld strength is reduced with increased tool rotational speeds. However, the strength can be improved by increasing traverse speed which adjusts the cooling rate and 
produce a finer Widmanstätten structure. Liu et al ${ }^{[51]}$ demonstrated this using three traverse speeds $(25$, 50 and $100 \mathrm{~mm} / \mathrm{min}$ ) and a constant rotation of $400 \mathrm{rpm}$ (figure 12).
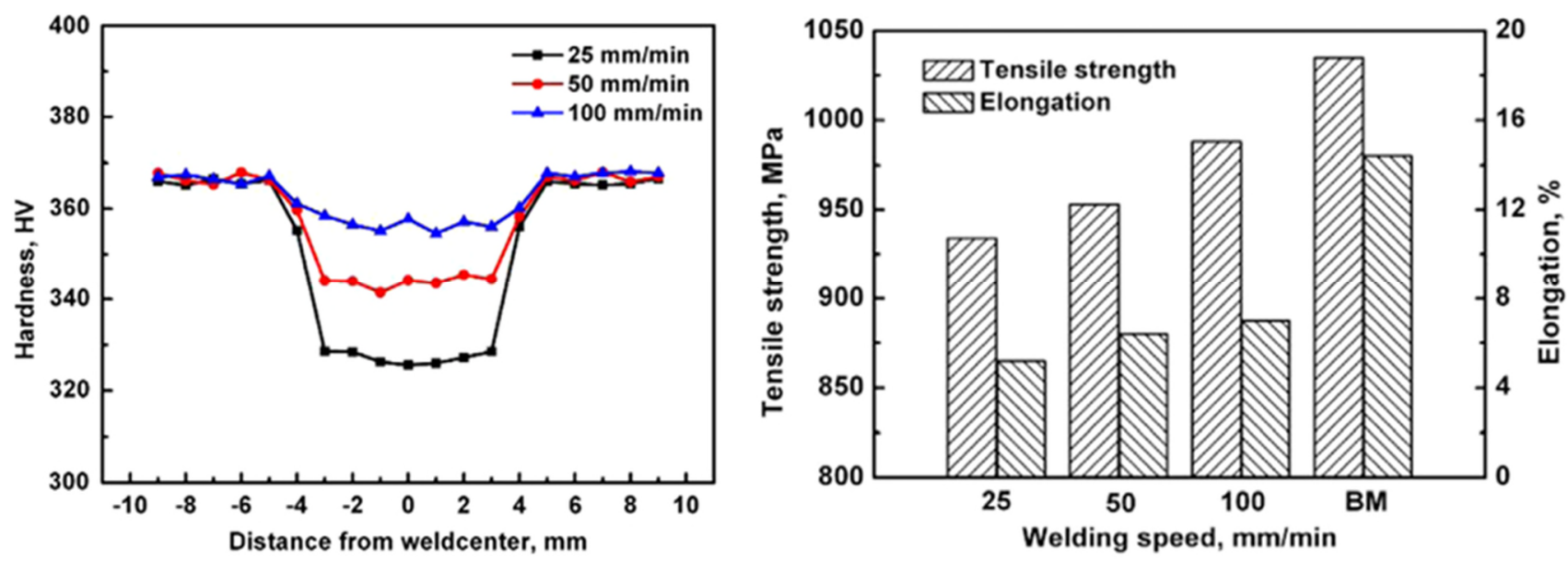

Figure 12 - The relationship of cooling rate determined by traverse speed was demonstrated on material hardness (left) and tensile strength (right) by Liu et al ${ }^{[51]}$ on $2 \mathrm{~mm}$ thick Ti 6Al-4V with a constant rotational speed.

Esmaily et al ${ }^{[49]}$ achieved much faster cooling rates in $4 \mathrm{~mm}$ joints using similar parameters to Zhou et $\mathrm{al}^{[50]}$ on $2 \mathrm{~mm}$ plate (figure 13). As already discussed there was evidence of reduced ductility due to $\alpha^{\prime}$ formation but much higher weld hardness was documented.
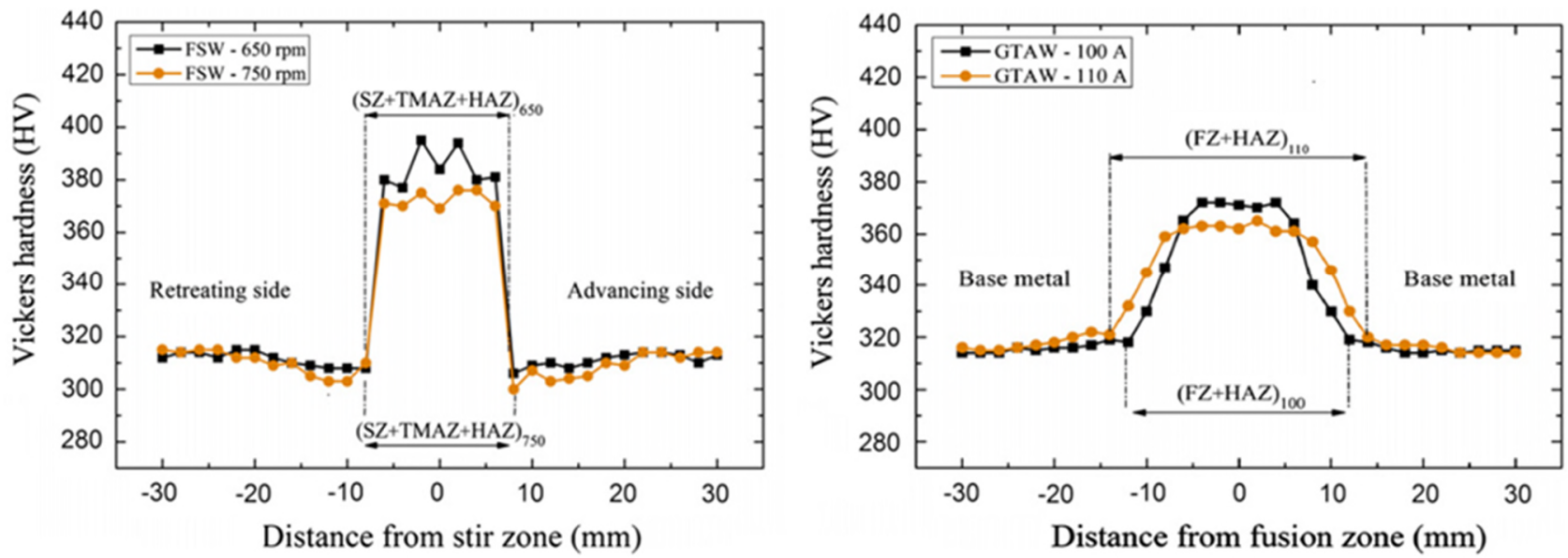

Figure 13 - Hardness profile across the weld, HAZ and base material in FSW and GTAW reported by Esmaily et al ${ }^{[49]}$.

Clearly a range of strength and hardness properties can be produced by FSW titanium alloys. Improved strength and weld hardness can be achieved but this is at the expense of ductility and fracture toughness. In several studies the tensile test failure occurs in the weld metal ${ }^{[50,51]}$, which would be 
considered unusual for a welds produced by GTAW or EBW. Failure in the weld metal is acceptable if higher than the strength of the base material specification.

\subsection{Fracture Toughness}

Sanders et al ${ }^{[52]}$ investigated the fracture toughness using compact tension specimens of $2.5 \mathrm{~mm}$ joints of Ti-6Al-4V in the as welded and PWHT condition. The fracture toughness of the stir zone was around $50 \%$ lower than the base metal in the as welded condition. The fracture toughness testing was in accordance with ASTM E561 using compact tension specimens. The properties were recovered to within $10 \%$ of the base material with PWHT.

A larger data set was produced by Edwards and Ramulu ${ }^{[53]}$ in $6 \mathrm{~mm}$ Ti $6 \mathrm{Al}-4 \mathrm{~V}$ joints using similar process parameters $(280 \mathrm{rpm}$ and $100 \mathrm{~mm} / \mathrm{min})$. Fracture toughness samples were prepared to assess the SZ in the longitudinal and transverse directions. Apparent fracture toughness was computed from maximum applied load $\left(\mathrm{K}_{\text {app }}\right)$. An average $\mathrm{K}_{\text {app }}$ value of $85 \mathrm{MPa} \sqrt{\mathrm{m}}$ was reported in the longitudinal direction and $70 \mathrm{MPa} \sqrt{\mathrm{m}}$ in the transverse representing a $7 \%$ and $25 \%$ reduction respectively comparable to the base material. The low values in the transverse direction were not fully explained and in contrast to data generated by Sanders et a ${ }^{[52]}$.

For propellant tank design $\mathrm{K}_{1 \mathrm{c}}$ values (plain strain fracture toughness) are preferred which are nominally in the range of $1200-1800 \mathrm{MPa} \sqrt{\mathrm{m}}^{[41]}$. The NASGRO database has $\mathrm{K}_{1 \mathrm{C}}$ values above 1700 $\mathrm{MPa} \sqrt{ } \mathrm{m}$ for EB welded Ti $6 \mathrm{Al}-4 \mathrm{~V}$.

\subsection{Residual Stress}

For $6 \mathrm{~mm}$ Ti $6 \mathrm{Al}-4 \mathrm{~V}$ joints, Edwards and Ramulu ${ }^{[53]}$ reported some residual stress measurements using notched Compact Tension (CT) specimens (ASTM E837 method 13a) in the as welded and stress relieved condition. In the longitudinal direction there were large tensile stresses and in the transverse large compressive stresses. The residual stress was negligible after an annealing treatment at $760^{\circ} \mathrm{C}$ for 45 minutes. 
Table 2 - Extract of Residual Stress Measurements (ASTM E837) by Edwards and Ramulu ${ }^{[53]}$

\begin{tabular}{|l|l|c|c|}
\hline \multirow{2}{*}{ Condition } & \multirow{2}{*}{ Gauge Location } & Longitudinal Stress & Transverse Stress \\
\cline { 3 - 4 } & Centre Line & $\mathbf{( M P a )}$ & $\mathbf{( M P a )}$ \\
\hline As Welded & Advancing Boundary & 368.9 & -59.3 \\
\hline & Base Metal & 414.4 & -57.9 \\
\hline Stress Relieved & Centre Line & 12.4 & 2.1 \\
\hline & Advancing Boundary & 3.4 & -6.2 \\
\hline & Base Metal & 9.0 & -4.8 \\
\hline
\end{tabular}

Edwards and Ramulu ${ }^{[54]}$ did a further investigation on the residual stresses in different plate thicknesses using the specimens presented in figure 10 . In the $3 \mathrm{~mm}, 6 \mathrm{~mm}$ and $9 \mathrm{~mm}$ joints the compressive stresses were in the transverse direction and the tensile stresses in the longitudinal direction. The $12 \mathrm{~mm}$ sample showed compressive stresses in the longitudinal plane. Tensile stresses in the longitudinal direction measured between 300 and $420 \mathrm{MPa}$ on the other specimens.

Edwards and Ramulu ${ }^{[54]}$ concluded that the high stresses were due to mechanical deformation and the rigid clamping used for restraint. Pasta and Reynolds ${ }^{[55]}$ used a different approach to determine residual stress in titanium FSW welds. Stress intensity data obtained from a fracture toughness test (CT) was used to calculate residual stresses transverse to the weld. Tensile stresses up to $200 \mathrm{MPa}$ were reported within the SZ with a transition to compressive in the HAZ. The major difference compared to the work by Edwards and Ramulu ${ }^{[53,54]}$ appears to be the welds had a lower heat input. X-Ray Diffraction (XRD) was performed by Steuwer et al ${ }^{[56]}$ and tensile stresses were encountered in the SZ (longitudinal direction) and mostly compressive stresses in the transverse and HAZ.

Whilst the residual stresses could be reduced with an annealing treatment there appears to be no benefit over fusion techniques in the as welded condition. Tensile residual stresses are more predominant in the longitudinal direction of the weld. Further work is required to verify the residual stresses especially sub-surface using a combination of hole drilling techniques, XRD and neutron diffraction methods.

\subsection{Corrosion Resistance}

Titanium and its alloys have high resistance to general corrosion and fusion welds are considered to have similar properties to the parent material in this respect. Weldments can become susceptible to 
corrosion when impurities such as iron, sulphur and oxygen are introduced ${ }^{[57]}$. Atapour et al ${ }^{[58]}$ compared the corrosion behaviour of Ti $6 \mathrm{Al}-4 \mathrm{~V}$ castings joined by GTAW and FSW and immersed in $5 \%$ Hydrochloric acid at room temperature. The FSW joint exhibited better corrosion resistance the fusion welds in the same conditions. They hypothesized that this was due to the lower peak temperatures and faster cooling rates in FSW process. Whilst both processes produced welds with prior $\beta$ grains with $\alpha+\beta$ lamellar there was much more grain growth in the GTAW welds. The microporosity that is present in GTAW welds was also concluded as being a factor as they act as corrosion initiation sites ${ }^{[58]}$. No characterisation of Ti 6Al-4V FSW joints by salt spray testing (ASTM B117) was performed.

Another corrosion mechanism is Stress Corrosion Cracking (SCC) which is of concern particularly in pressurised vessels in contact with aggressive propellants. Titanium alloys have a very high level of resistance to SCC in most environments as detailed in ECSS-Q-ST-70-36 (Material Selection for Controlling Stress Corrosion Cracking). Titanium becomes susceptible to SCC in contact with chlorides, fluorides and methanol ${ }^{[57]}$. For space propulsion, Mixed Oxides of Nitrogen (MON-1) and Nitrogen Tetroxide $\left(\mathrm{N}_{2} \mathrm{O}_{4}\right)$ can induce SCC in titanium alloys if the Nitric Oxide (NO) percentage becomes too low ${ }^{[59]}$. Despite this titanium alloys are used for pressure vessels and the quality of the propellants has to comply with stringent specifications. Weldments would have to show comparative performance to the base material. No test data was found relating to the SCC performance of FSW in titanium alloy. The lack of data and the residual stresses (tensile) already identified in the FSWs would require dedicated SCC tests in sodium chloride environment as per ECSS-Q-ST-70-37 or ASTM G58.

\section{Developments and Future Work}

\subsection{Stationary Shoulder FSW}

The TWI Stationary Shoulder Friction Stir Welding (SSFSW) tool has proven to be a significant development for joining low conductivity material such as titanium alloys. By removing the frictional heat at the surface it introduces a constant heat input through the weld profile and reduces overheating at the surface. The current generation of tooling design incorporate a water cooling system and argon gas delivery for shielding ${ }^{[60]}$. A cross section of the SSFSW tool developed by TWI is shown in figure 14. 

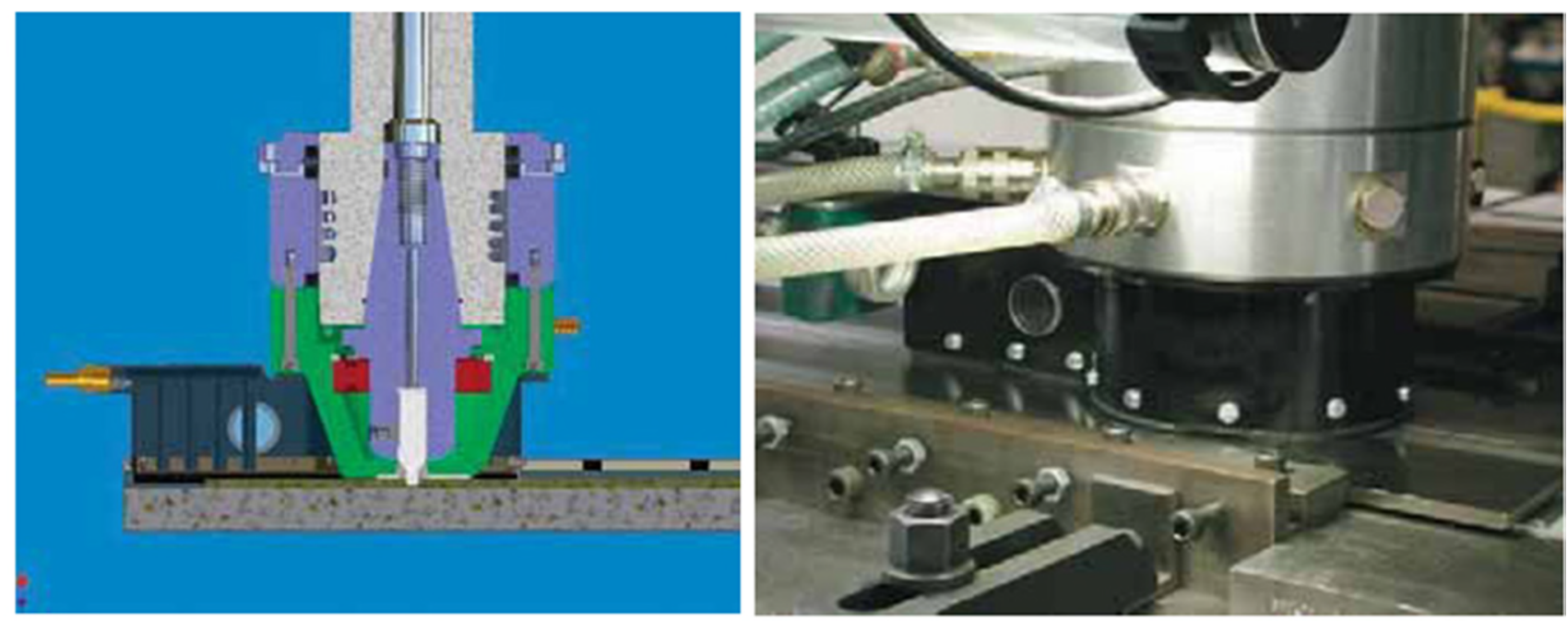

Figure 14 - Left: Schematic of the SSFSW prototype developed by TWI. Right: The TWI prototype SSFSW used in the first trials with titanium alloys ${ }^{[61]}$.

TWI have performed successful trials of the technology with CP titanium and alloyed titanium. The process also produced smoother weld profiles than the conventional shoulder designs. The peak thermal exposure is reduced compared to the standard FSW process. The overall improved temperature control also reduces tool wear ${ }^{[20,62]}$. Davies et al ${ }^{[63]}$ performed a metallurgical evaluation of SSFSW produced in $6.35 \mathrm{~mm}$ Ti $6 \mathrm{Al}-4 \mathrm{~V}$ plate. Although the $\mathrm{SZ}$ was still above the $\beta$ transus the microstructure was more uniform through the weld depth.

\subsection{Variable Penetration Tool}

A Variable Penetration Tools (VPT) has been designed and patented by the Edison Welding Institute which has a very small shoulder arrangement and conical pin. It is claimed that the tool has longer life and is more robust for high temperature materials. Prototype structures were made with only minimal tool wear. An additional benefit is the possibility to extract the tool without leaving an exit feature ${ }^{[64]}$. The frictional heating with the shoulder prior to pin insertion may also help reduce tool wear.

\subsection{Arc Enhanced FSW}

The Wisconsin Alumni Research Foundation (WARF) has filed a patent in the USA for a modified FSW technique using an arc to pre-heat the weld joint. The technique is termed 'Arc-Enhanced Friction Stir Welding' and is protected under patent US,7078,647 B2 granted in 2006 ${ }^{[65]}$. The invention is aimed towards high temperature materials where excessive tool degradation has been experienced. By using 
a GTAW or plasma torch to raise the joint temperature in advance of the FSW tool (figure 15) this will drastically reduce tool wear and forging loads.

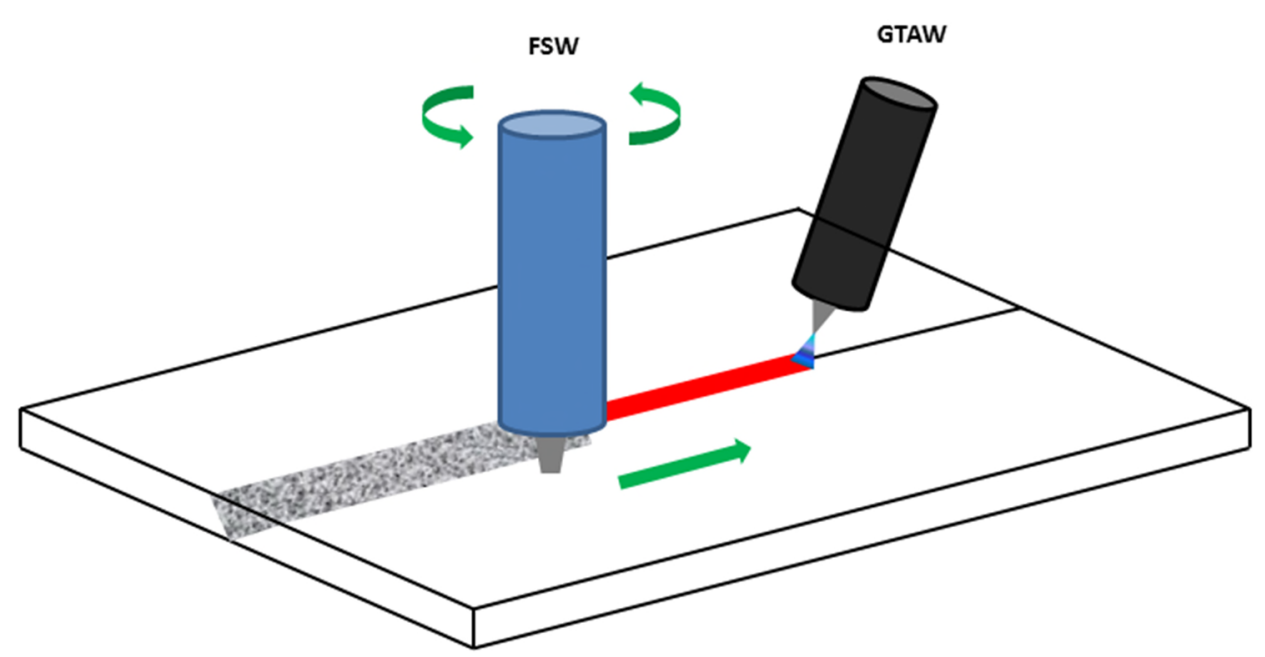

\section{Figure 15 - Arc Enhanced FSW hybrid technique invented by Wisconsin Alumni Research Foundation and protected under US patent US,7078,647 B2 ${ }^{[65]}$.}

No literature is available for titanium alloys but Bang et al ${ }^{[66]}$ successfully used the approach for a FSW transition joint of aluminium (AA 6061) and austenitic stainless steel (AISI 304). The same technique using a GTAW pre-heat was also applied to AA 6061 to Ti 6Al-4V joints by Bang et al ${ }^{[67]}$. Only limited characterisation was performed included hardness tests, tensile test and microstructural examination and the joint properties were above that of the aluminium alloy.

\subsection{Ultrasonic Assisted FSW}

Another evolution of the FSW involves the introduction of ultrasonic motion at the tool to increase heat generation. The technique is suitable for higher temperature materials where traditional FSW has not prospered. In a thesis study by Park ${ }^{[68]}$, it was found that forging loads can be reduced by $6 \%$ during the plunge stage and 12\% when traversing with Ultrasonic Assisted FSW (UAFSW) on aluminium alloys. Amini and Amiri ${ }^{[69]}$ demonstrated a $25 \%$ reduction in vertical forces using identical parameters with AA 6061 alloy. 


\section{Propellant Tank Applications}

This section investigates the challenges associated with applying FSW to titanium propellant tank applications.

\subsection{Modified Tank Designs}

As stated in section 3 backing bars are required under the FSW tool. Opening up the hemispherical ends of the tank could allow internal fixturing to be used for the girth welds. This would also simplify the hemisphere forgings and reduce material costs. An expensive purpose built fixture would be necessary for each tank product. The fixture would need to be hydraulically operating to provide internal backing around the inner circumference. The tooling could be extracted through the boss ends of the vessel and the closure weld completed with a GTAW process.
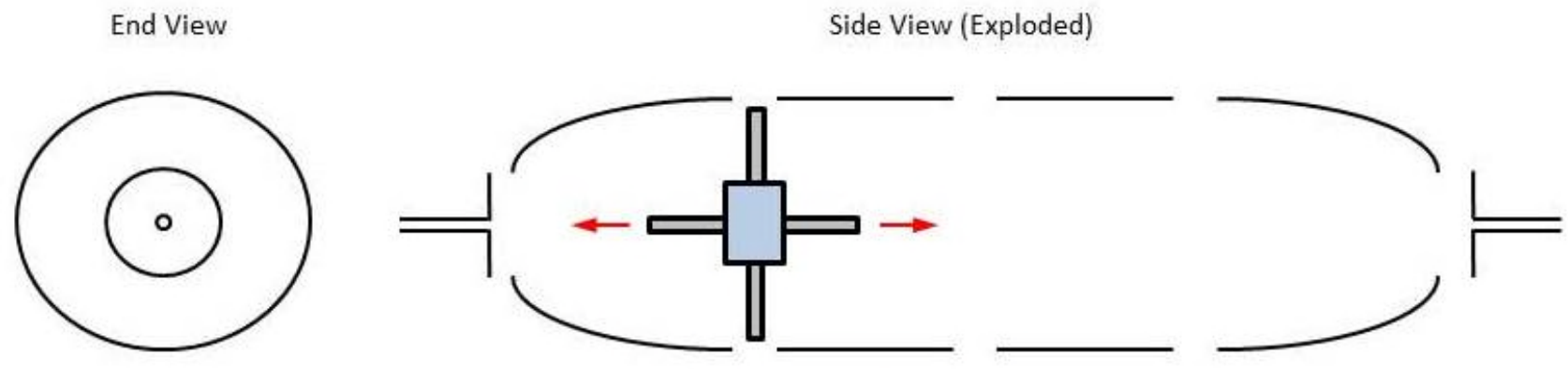

Figure 16 - Modified tank design. The exploded view shows a tank cross-section and the weld joint locations. An increased opening at each end would allow more access for internal fixtures.

There may also be scope for introducing longitudinal weld seams but this brings complexities related to the roundness of the vessel. Longitudinal weld seams are already employed on cylindrical tanks which are overwrapped with CFRP.

\subsection{New Joint Configurations}

Alternatively if backing bars/ fixturing cannot be used it may be possible to weld without support using either modified joint design or minimizing forging loads. The joint thickness would need to be increased to resist forging loads in the $\mathrm{z}$ direction. This is limited to a few millimetres as it would interfere with propellant expulsion in a zero gravity environment towards the end of life of the spacecraft. Outer diameter circumferential flanges could also be introduced to aid clamping and resist 
forging and torque loads in the $\mathrm{x}$ and $\mathrm{y}$ axis. The additional stiffness of the joint would have a positive impact on the burst margins of the tank but would introduce a mass penalty. The finished weld would accommodate a notch where the maximum point of penetration but as propellant tanks are not subject to fatigue this could be acceptable. Propellant entrapment in the gap would be similar to existing J type designs shown in figure 2. The majority of welds on propulsion hardware are only partially penetrating to avoid internal contamination of propellant contact surfaces. The joint configuration would have an estimated $1 \%-2 \%$ increase in mass on a tank with three girth welds. Additional processing of the weld crown would be necessary to remove any toe flash or tool extraction features that would cause stress concentrations. It is considered feasible to remove toe flash for small vessels using spin polishing but not practical for larger volume tanks.
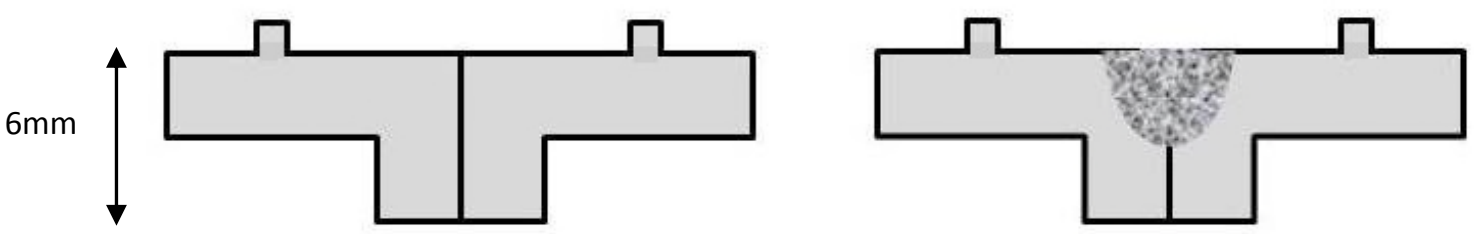

Figure 17 - Proposed weld joint to improve resistance against FSW forging loads. Clamping features are included on the outer diameter and a deeper flange arrangement on the inner diameter.

\subsection{Novel Applications}

Another design concept which would be innovative to the industry would be to use dissimilar materials in a tank configuration. The applications would be limited to bladder tanks (BTO1 tank in figure 1) where the fuel and gas are separated by a polymeric flexible membrane (diaphragm). The pressure differential provides positive expulsion of the propellant without the two media mixing ${ }^{[70]}$. 


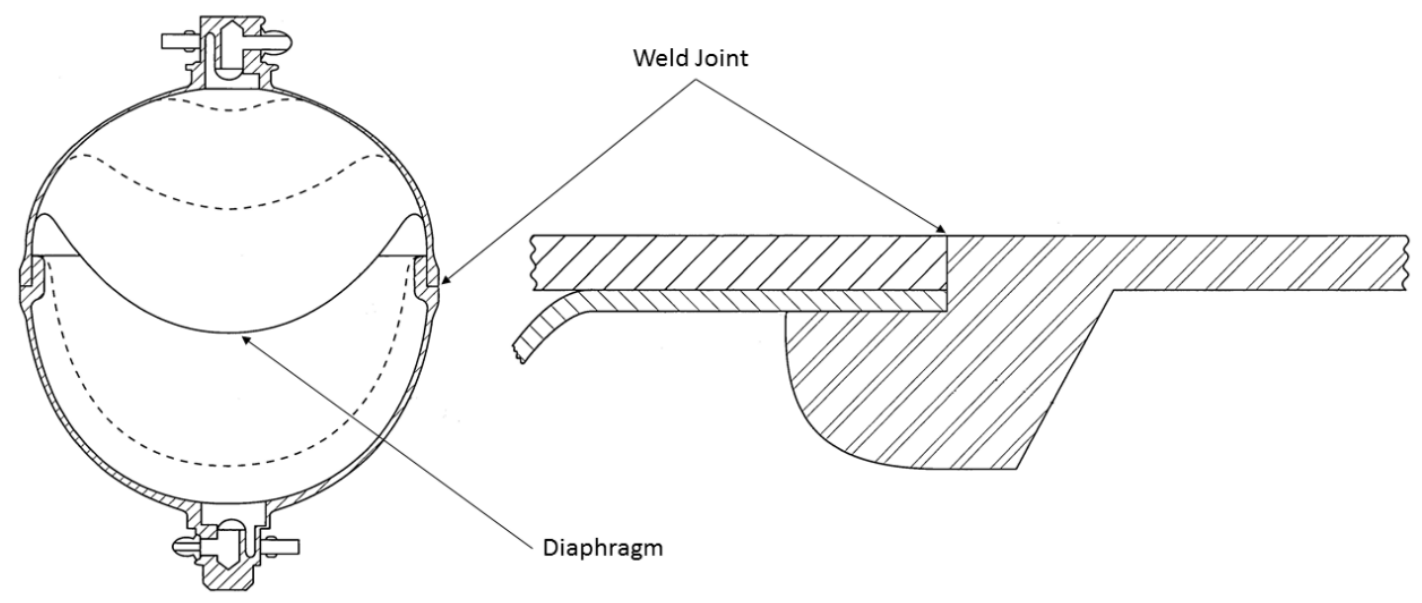

Figure 18 - Basic concept of bladder tank designs used in propellant tanks to segregate the pressurisation gases and propellants ${ }^{[71]}$.

The propellant contact side of the vessel could be manufactured from titanium alloy and the gas contact of a lower density aluminium alloy to reduce mass. A hybrid vessel of two commonly used tank materials such as AA 2219 and Ti 6Al-4V could warrant further investigation. Dissimilar joints between 6000 series aluminium alloys and Ti 6Al-4V have been successfully welded with FSW ${ }^{[72]}$. Bladder tanks (figure 18) are not as common as PMD tank types shown in figure 1. 


\section{Discussion}

The FSW process has demonstrated potential with respect to producing acceptable welds in Ti 6Al$4 \mathrm{~V}$ alloy. The majority of the data generated is for small lengths of weld and therefore not proven for an industrial application. To become suitable for the manufacture of titanium pressure vessels there are several important challenges to overcome:-

- Reduce tool wear and costs

- Expand process window

- Reduce forging loads

- Verify compatibility with space propellants

- Modify tank and weld joint design

The tungsten based tools available have demonstrated high weld quality albeit for short lengths of weld. W-Re and W-La have been favoured to date with titanium alloys. Advancements in the composition and properties of these tools merits further investment but the issue of high forging loads would still be problematic for pressure vessels. As already discussed joint modification would help but rationalising additional mass would be disadvantageous for the technology. Minimising forging loads will be possible with detailed Design of Experiments (DoE) but process evolutions such as ArcEnhanced and Ultrasonic Assisted FSW offer the most promise.

From the literature available it is clear that similar weld strength and hardness can be attained to that of a fusion welding methods. Fracture toughness properties however need further investigation as there appears to be a deficit over conventional welding processes in the as welded condition. The peak welding temperature across a range of parameters and joints is in the region $950^{\circ} \mathrm{C}-1100^{\circ} \mathrm{C}$. All welding is done with argon shielding and hardness plots across the joints suggest that embrittlement is not a problem with FSW. However, hardness testing of titanium welds is not the best method to detect embrittlement due to the large grain sizes. The fracture toughness tests indicate that embrittlement might be an issue, which needs further assessment. Chemical analysis is also necessary to confirm gas levels dissolved in the weld zone.

The relationship between fracture toughness and residual stresses needs to be better understood. As part of the motivation for the introduction of FSW for propellant tanks it was envisaged that reduced residual stresses would be demonstrated but this appears not to be the case. As with current practice all welding properties can be tuned by heat treatment so this is not a show stopper. Ti $6 \mathrm{Al}-4 \mathrm{~V}$ can be 
stress relieved or aged in a similar temperature range $\left(480^{\circ} \mathrm{C}-650^{\circ} \mathrm{C}\right)$ for 1 to 8 hours so the weld properties can be adjusted to meet the design requirements for all metallic vessels.

The resistance to various forms of corrosion are serious aspects of tank weldments. Loss of structural integrity or containment would have catastrophic implications in space or on the ground. The likelihood of FSW decreasing the resistance of titanium alloys to corrosion is low but the necessary tests need to be done to build confidence in the process. High profile failures have occurred in the past with pressure vessels where the interaction between weldments, cleaning fluids, pressurised environment and propellants have had disastrous consequences.

Development of FSW for titanium alloys is in the early stages and significant funding is required to raise the maturity level. This is also evident from the 1.2 million Euro investment by ESA to advance the TRL to a prototype stage. The end result may be that FSW cannot be applied in the same way as for aluminium alloys and needs to evolve to become appealing for titanium alloys. A hybrid approach using a leading arc or plasma to raise the joint temperature prior to FSW seems a viable solution with a lot of potential.

Despite the promising evolution of FSW the existing joining methods still have their own merits. EB welding and GTAW are very well understood and if implemented and controlled appropriately produce very good quality welds. The high cost of space missions means that proven technology with space flight heritage is always preferred and the rationale for change must be convincing.

The potential is evident for FSW in relation to titanium alloys but the process should also be viewed with some scepticism. The process is not currently applied for titanium in the space industry but this can be explained due to the small amount of structural components made from titanium alloys. In the aerospace sector titanium is much more common. Titanium is used in abundance for compressor rotor drums on combustion engines (RB211, Trent) where these parts are manufactured with many meters of circumferential EB welds across hundreds of engines ${ }^{[8]}$. This would seem an ideal application for FSW if it were deemed a superior process to EBW and showed other benefits related to economics etc. Companies such as Rolls-Royce and General Electric still use EBW and rotary friction welding for these critical parts. Rolls-Royce has elected to optimise the EBW process to reduce vacuum cycles rather that look at alternatives ${ }^{[73]}$. The established design incorporating EBW on the RB211 and Trent engine families maybe make changing to developing technologies more difficult. This does not suggest that FSW should be dismissed but emphasizes that established methods are also evolving and remain competitive for the more novel joining processes. 


\section{Conclusions}

The main conclusions from this review are as follows:-

- Ti-6Al-4V alloy has been successfully welded in sections from $1 \mathrm{~mm}-25 \mathrm{~mm}$ in experimental conditions. Despite these results the technology is still not fully mature with respect to titanium.

- W-Re and W-La tools have been the focus of development and process optimisation studies for titanium alloys. Additions of Hafnium Carbide offer improved properties for W-Re tools and requires more research.

- Pin material is still considered a limiting factor for the FSW process for titanium alloys. Further development is required to improve tool life, optimise parameters and reduce costs.

- The new development of Stationary Shoulder FSW tools are considered a step change in the evolution of the process. The reduced temperature input and smooth weld profiles could have potential for titanium propellant tanks.

- Residual stresses need to be better understood as initial research suggests no apparent benefit over fusion welding techniques.

- The reduced fracture toughness of the weld zone requires more research to understand how it can be improved through processing and heat treatment.

- Limited information is available for the corrosion and stress corrosion cracking resistance for titanium weldments produced by the FSW process. The performance relative to conventional welds in salt spray tests, nitric acid immersion and Stress Corrosion Cracking tests needs to be understood.

- To implement FSW as a joining method on titanium propellant tanks a change to the design concept and manufacturing of the whole vessel would need to be considered. The rigidity at the joint may need to be increased to resist the forging loads of the process.

- The entrance and exit of the tooling on a circumferential weld presents a challenge that needs to be overcome. Variable penetration tooling is a promising development in this regard.

- A hybrid arc-assisted FSW method could be the evolution required to make the process more suitable for titanium alloys. The lack of investment and study in this approach thus far may be due to it eliminating the economic benefits of FSW. 


\section{References}

[1] Fortescue P, Swinerd G, Stark J. Spacecraft Systems Engineering. 4th edn. West Sussex: J. Wiley \& Sons Ltd; 2011.

[2] European Space Agency. Clean Space - Green Technology. 2014. Available at: http://www.esa.int/Our_Activities/Space_Engineering_Technology/Clean_Space/Green_technologies (Accessed July 2015).

[3] ANSI AIAA S-080. Space Systems - Metallic Pressure Vessels, Pressurised Structures and Pressure Components. American Institute of Aeronautics and Astronautics. Reston, Virginia, USA; 1998.

[4] Debreceni M J, Kuo T K, Jaekle D E. Development of a Titanium Propellant Tank. $39^{\text {th }}$ AIAA/ASME/SAE/ASEE Joint Propulsion conference. $20^{\text {th }}-23^{\text {rd }}$ July. Huntsville, Alabama: p.4604; 2003.

[5] Tam W H, Kawahara G H, Jaekle D E, Larsson L W. Design and Manufacture of a Propellant Tank Assembly. $36^{\text {th }}$ AIAA/ASME/SAE/ASEE Joint Propulsion conference. Huntsville, Alabama: p.3444. 2000.

[6] EADS Astrium GmbH. Spacecraft Propellant Tank Manufacture. Available at:

http://cs.astrium.eads.net/sp/spacecraft-propulsion/propellant-tanks/manufacturing.html (Accessed July 2015).

[7] European Space Agency. Launch Vehicles - Ariane 5. 2015. Available at:

http://www.esa.int/Our_Activities/Launchers/Launch_vehicles/Ariane_5 (Accessed June 2015).

[8] Schultz H. Electron Beam Welding. Cambridge: Abington Publishing; 1993.

[9] Buhl N, Wagner G, Eifler D, Gutensohn M, Zillekens F. Microstructural and Mechanical Investigations of Friction Stir Welded Ti/Ti and Ti Alloy/ Ti Alloy Joints. Friction Stir Welding Processes VII. p. 141 - 149; 2013.

[10] Rummel W D. Recommended Practice for demonstration of non-destructive evaluation reliability in aircraft parts. Materials Evaluation - Volume 40, p. 922 - 931; 1982.

[11] NASA. Non-Destructive Evaluation Requirements for Fracture Critical Metallic Components. 1996. Available at: https://standards.nasa.gov/training/nasa-std-5009/index.html (Accessed July 2015).

[12] Raj B, Jayakumar T and Thavasimuthu M. Practical Non-Destructive Testing. 3rd Edn. Oxford, United Kingdom: Alpha Science International Ltd; 2009.

[13] Ecord G M. NASA TN D-6975: Apollo Experience Report - Pressure Vessels. NASA Manned Spacecraft Centre. Houston, Texas; 1972.

[14] Ding J. Carter B, Lawless K, Nunes A, Russel C, Suites M, Schneider J.. A Decade of Friction Stir Welding R \& D at NASAs Marshall Space Flight Centre. NASA Marshall Space Flight Centre, Huntsville, Alabama, USA; 2006.

[15] Thomas W M, Nicholas E D, Needham J C, Murch M G, Temple-Smith P, Dawes C J. The Welding Institute. Improvements relating to Friction Welding. International Patent Application. PCT/GB92/02203; 1992.

[16] The Welding Institute. Friction Stir Welding Patents - A Stirring Story. Available at: http://www.twi-global.com/newsevents/case-studies/friction-stir-welding-patents-a-stirring-story-002/ (Accessed August 2015).

[17] The Welding Institute. Knowledge Summary - Friction Processing Technology. Available at: http://www.twiglobal.com/technical-knowledge/knowledge-summaries/friction-processing-technologies/ (Accessed July 2015).

[18] Lohwasser D. and Chen Z. Friction Stir Welding - From Basics to Application. Cambridge: Woodhead Publishing Limited; 2010.

[19] Thomas W M, Norris I M, Staines D G, Watts E R. Friction Stir Welding - Process Developments and Variant Techniques. The Society of Manufacturing Engineers Conference: Wisconsin, $3^{\text {rd }}-4^{\text {th }}$ August; 2005. 
[20] Russell M. J, Blignault C, Horrex N L, Wiesner C S. Recent Developments in the Friction Stir Welding of Titanium Alloys. Welding in the World. Vol. 52(9): p. 12 - 15; 2008.

[21] Lauro A. Friction Stir Welding of Titanium Alloys. Welding International Journal, vol. 26(1), p. 8-21; 2011.

[22] Edwards P D, Ramulu M. Peak Temperatures During Friction Sit Welding of Titanium 6Al-4V. Science and Technology of Welding and Joining. Vol 15(6): p.468 - 472; 2010.

[23] Shtrikman M M. Trends in the Development of the Friction Stir Welding Process. Welding International Journal, vol. 29(3), p.230 . 239; 2015.

[24] European Space Agency. GSTP-6 Element 1 - Compendium of Potential Activities Advanced Manufacturing. TEC-T/2015-013/NP. European Space Agency: Noordwijk, Netherlands; 2015.

[25] European Space Agency. Technology Readiness Levels. 18th June 2015. Available at: http://sci.esa.int/sre-ft/50124technology-readiness-level/ (Accessed September 2015).

[26] Crocker A M, Doering K B, Meadows R G. Update on Risk Reduction Activities for an F-1-based Advanced Booster for NASAs Space Launch System. 50 ${ }^{\text {th }}$ AIAA/ASME/SAE/ASEE Joint Propulsion conference, $28^{\text {th }}-30^{\text {th }}$ July; 2014.

[27] Threadgill P L, Leonard A J, Shercliff H R, Withers P J. The Welding Institute. Friction Stir Welding of Aluminium Alloys. 2009. Available at: http://www.twi-global.com/technical-knowledge/published-papers/friction-stir-weldingof-aluminium-alloys/ (Accessed August 2015).

[28] Edwards P D, Coleman G, Petersen M, Cotton J. Mechanical Properties of Thick Section Titanium 6Al-4V Friction Stir and Electron Beam Welds. Mishra R, Mahoney M W, Sato Y, Hovanski Y, Verma R (Eds.). Friction Stir Welding and Processing VI: California, Wiley and sons inc. Seatle, USA: p. 73 - 79; 2011.

[29] Zhang Y N, Cao X, Larose S, Wanjara P. Review of Tools for Friction Stir Welding and Processing: Canadian Metallurgical Quarterly. Montreal, Canada. Vol. 51; p. 250 - 261; 2012.

[30] Edwards P D, Ramulu M. Material Flow during Friction Stir Welding of Ti-6Al-4V. Journal of Materials Processing Technology. Vol. 218: p. 107 - 115; 2015.

[31] Thompson B. Tungsten Based Tool Material Development for the Friction Stir Welding of Hard Metals. Mishra R, Mahoney M W, Sato Y, Hovanski Y, Verma R (Eds.). Friction Stir Welding and Processing VI: California: Wiley and sons inc. Seatle, USA: p. $105-112 ; 2011$.

[32] Edwards P D, Ramulu M. Investigation of Microstructure, Surface and Subsurface Characteristics in Titanium Alloy Friction Stir Welds of Varied Thicknesses. Science and Technology of Welding and Joining. Vol 14(5): p.476 - 483; 2009.

[33] Edwards P D, Ramulu M. Effect of Process Conditions on Superplastic Forming Behaviour in Ti-6Al-4V Friction Stir Welds. Science and Technology of Welding and Joining. Vol 14(7): p.669-680; 2010.

[34] Buffa G, Fratini L, Micari F. On the Choice of Tool Material in Friction Stir Welding of Titanium Alloys. North American Manufacturing Research Conference, Notre Dame, Indiana, USA: Vol. 40; 2012.

[35] Thompson B. Tool Degradation Characterization in the Friction Stir Welding of Hard Metals. MSc Thesis. Ohio State University; 2010.

[36] Thompson B. Friction Stir Welding of Hard Metals Using Advanced Refractory Alloys - Report No. MR1013. EWI Cooperative Research Program Report; 2010.

[37] Rai R, De A, Bhadeshia H K D H, Debroy T. Review Friction Stir Welding Tools. Science and Technology of Welding and Joining. Vol 16(4): p.325 - 342; 2011. 
[38] Zhang Y, Sato Y S, Kokawa H, Park S H C, Hirano S. Stir Zone Microstructure of Commercial Purity Titanium Friction Stir Welded using PCBN Tool. Materials Science and Engineering Journal. Vol 488: p. 25 - 30; 2008.

[39] Kumar N, Rodelas J, Mishra R S. The Effects of Friction Stir Processing on the Microstructural Evolution and Mechanical Properties of Ti-6Al-4V Alloy. Friction stir welding and processing. TMS Annual Meeting; San Francisco, CA. p. 45-53; 2009.

[40] Mishra R S, Mahoney M W. Friction Stir Welding and Processing. Materials Park, OH, ASM International; 2007.

[41] Materials Properties Handbook: Titanium Alloys, Boyer R, Welsch G, Collings E W. Cleveland, Ohio: ASM International; 1994.

[42] Lütjering G, Williams J C. Titanium. 2nd edn. New York: Springer; 2007.

[43] Porter D A, Easterling K E. Phase Transformations in Metals and Alloys. Berkshire: Van Nostrand Reinhold (UK) Co. Ltd; 1981.

[44] Metals Handbook, Vol.2. Properties and Selection - Nonferrous Alloys and Special-Purpose Materials. 10th Edn. ASM International. Cleveland, Ohio. p.183; 1990.

[45] Thomas W M, Staines D G, Norris I M, de Frias R. Friction Stir Welding - Tools and Developments. Welding World, Vol. 47 (11): p. $10-17 ; 2002$.

[46] Deformation Induced Abnormal Grain Growth in Friction Stir Weld During Solution Heat Treatment. Available at: https://www.linkedin.com/pulse/deformation-induced-abnormal-grain-growth-friction-stir-anupam-kundu (Accessed March 2016). Written by Anupam Kundu.

[47] Zhang Y, Sato Y S, Kokawa H, Park S H C, Hirano S. Microstructural Characteristics and Mechanical Properties of Ti-6Al-4V Friction Stir Welds. Materials Science and Engineering. Vol. 485(1): p. 448 - 455: 2008.

[48] Kitamura K, Fujii H, Iwata Y, Sun Y S, Morisada Y. Flexible Control of the Microstructure and Mechanical Properties of Friction Stir Welded Ti-6Al-4V Joints. Materials and Design Journal. Vol. 46: p.348 - 354; 2013.

[49] Esmaily M, Mortazavi S N, Todehfalah P, Rashidi M. Microstructural Characterisation and Formation of $\alpha$ ' Martensite Phase in Ti-6Al-4V Alloy Butt Joints Produced by Friction Stir and Gas Tungsten Arc Welding Processes. Materials and Design. Vol. 47: p. 143 - 150: 2013.

[50] Zhou L, Liu H J, Liu Q W. Effect of Rotation Speed on Microstructure and Mechanical Properties of Ti-6Al-4V Friction Stir Welded Joints. Materials and Design. Vol. 31: p. 2631 - 2636; 2010.

[51] Liu H J, Zhou L, Liu Q W. Microstructural Characteristics and Mechanical Properties of Friction Stir Welded Joints of Ti-6Al-4V Titanium Alloy. Materials and Design. Vol. 31: p. 1650 - 1655; 2010.

[52] Sanders D G, Edwards P, Cantrell A M, Gangwar K, Ramulu M. Friction Stir-Welded Titanium Alloy Ti-6Al-4V: Microstructure, Mechanical and Fracture Properties. Journal of Minerals, Metals and Materials. Vol 67(5): p. 1054 $1063 ; 2015$.

[53] Edwards P D, Ramulu M. Fracture Toughness and Fatigue Crack Growth in Ti-6Al-4V Friction Stir Welds. Fatigue and Fracture of Engineering Materials and Structures. Vol. 38: p. 970 - 982: 2015.

[54] Edwards P D, Ramulu M. Surface Residual Stresses in Ti-6Al-4V Friction Stir Welds Pre- and Post-Thermal Stress Relieve. Journal of Materials and Engineering Performance. Vol 24(9): p.3263 - 3270; 2015.

[55] Pasta S, Reynolds A P. Residual Stress Effects on Fatigue Crack Growth in a Ti-6Al-4V Friction Stir Weld. Fatigue and Fracture of Engineering Materials and Structures. Vol. 31: p. 569 - 580: 2008.

[56] Steuwer P, Hattingh D G, James M N, Singh U, Buslaps T. Residual Stresses, Microstructure and Tensile Properties in Ti-6Al-4V Friction Stir Welds. Science and Technology of Welding and Joining. Vol. 17(7): p. 525 - 533; 2012. 
[57] Donachie M. J. Titanium - A Technical Guide. $2^{\text {nd }}$ edn. Cleveland, Ohio: ASM International; 2000.

[58] Atapour M, Pilchak A L, Frankel G S, Williams G C. Corrosion Behaviour of Friction Stir Processed and Gas Tungsten Arc Welded Ti-6Al-4V. Metallurgical and Materials Transactions. Vol. 41(9): p. 2318 - 2327; 2010.

[59] Bussu G, Stramaccioni D, Kalsch I. Experimental Assessment of the Susceptibility to Stress Corrosion Cracking of Ti6Al-4V Alloy Exposed to MON-1 Propellant Tank Environment. ESA International Propulsion Conference: Sardinia; 2-4 June 2004.

[60] Russell M J, Threadgill P L, Thomas M J, Wynne B P. Static Shoulder Friction Stir Welding of Ti-6Al-4V. 11th World Conference on Titanium, Kyuoto, Japan. Japan Institute of Metals: p.1095 - 1098; $3^{\text {rd }}-7^{\text {th }}$ July, 2007.

[61] The Welding Institute. Friction Stir Welding - Static shoulder friction stir welding of Ti-6Al-4V; process and evaluation. 2007. Available at: http://www.twi-global.com/technical-knowledge/published-papers/static-shoulderfriction-stir-welding-of-ti-6al-4v-process-and-evaluation-june-2007/. (Accessed February 2017).

[62] The Welding Institute. Friction Stir Welding - Process Variants and Recent Industrial Developments. 2007. Available at: http://www.twi-global.com/EasysiteWeb/getresource.axd?AssetID=2846145 (Accessed September 2015).

[63] Davies P S, Wynne B P, Rainforth W M, Thomes M J, Threadgill P L. Development of Microstructure and Crystallographic Texture during Stationary Shoulder Friction Stir Welding of Ti-6Al-4V. Metallurgical and Materials Transactions. Vol 42(8): p. 2278 - 2289; 2010.

[64] Stotler T, Bernath J. Friction Stir Welding Advances - Edison Welding Institute. Advanced Materials and Processes. Vol 167(3): p. $35-37 ; 2009$.

[65] Kou S, Cao G. Wisconsin Alumni Research Foundation. Arc-Enhanced Friction Stir Welding. Patent No. US,7078,647 B2; 2006. Available at: http://www.warf.org/documents/ipstatus/P05041US.PDF (Accessed September 2015).

[66] Bang H, Bang H, Jeon G, Oh I, Ro C. Gas Tungsten Arc Welding Assisted Hybrid Friction Stir Welding of Dissimilar Materials AA 6061-T6 Aluminium Alloy and STS 304 Stainless Steel. Materials and Design. Vol. 37: p. 48 - 55; 2012.

[67] Bang H, Bang H, Song H, Joo S. Joint Properties of Dissimilar Al6061-T6 Aluminum Alloy to Ti-6\%Al-4\%V Titanium Alloy by Gas Tungsten Arc Welding Assisted Hybrid Friction Stir Welding. Materials and Design. Vol. 51: p. $544-551 ; 2013$.

[68] Park K. Development and Analysis of Ultrasonic Assisted Friction Stir Welding Process. PhD thesis. University of Michigan; 2009.

[69] Amini S, Amiri M. R. Study of Ultrasonic Vibration Effects of Friction Stir Welding. International Journal of Advanced Manufacturing Technology. Vol. 73: p. 127 - 135: 2014. A

[70] Lapilli G, Wise B, Gutierrez H, Kirk D. Characterisation of Elastomeric Diaphragm Motion with a Spacecraft Tank During Ground Operation. 51 ${ }^{\text {st }}$ AIAA/ASME/SAE/ASEE Joint Propulsion conference. Orlando, Florida: 2015.

[71] Friction Stir Welded Bladder Fuel Tank. 2011. Available at: https://www.google.com/patents/US8079126 (Accessed February 2016).

[72] Wu A, Song Z, Nakata K, Liao J, Zhou L. Interface and Properties of the Friction Stir Welded Joints of Titanium Alloy Ti6Al4V with Aluminium Alloy 6061. Journal of Materials and Design. Vol. 71: p. 85 - 92: 2015.

[73] Edison Welding Institute. Modelling the Electron Beam Welding of Intermediate Pressure Compressor Drums. RollsRoyce; 2014. Available at: http://ewi.org/eto/wp-content/uploads/2014/10/12-Beech-2014-Seattle-EB-Welding.pdf (Accessed October 2015). 


\begin{tabular}{|c|c|c|c|c|c|}
\hline Reference & $\begin{array}{l}\text { Alloy } \\
\text { Thickness (mm) } \\
\text { Form }\end{array}$ & $\begin{array}{l}\text { Tool material } \\
\text { Profile (deg.) } \\
\text { Dimensions (mm) }\end{array}$ & $\begin{array}{l}\text { Rotation (rpm) } \\
\text { Traverse (mm/min) } \\
\text { Tilt (deg.) }\end{array}$ & $\begin{array}{l}\text { Tensile Strength (MPa) } \\
\text { Yield Strength (MPa) } \\
\text { Hardness (Hv) }\end{array}$ & Additional test information \\
\hline $\begin{array}{l}\text { Edwards and Ramulu, } \\
2015\end{array}$ & $\begin{array}{c}\text { Ti } 6 \text { Al-4V } \\
6 \\
\text { plate } \\
\end{array}$ & $\begin{array}{c}\text { W-La } \\
\text { tapered } \\
- \\
\end{array}$ & $\begin{array}{c}280 \\
100 \\
- \\
\end{array}$ & $\begin{array}{c}1016-1045 \\
971-978 \\
335(\mathrm{SZ}) \\
\end{array}$ & $\begin{array}{l}\text { - Fracture toughness values of } 70-85 \mathrm{~K}_{\text {app }}(\mathrm{MPa} \sqrt{\mathrm{m}}) \\
\text { measured }\end{array}$ \\
\hline $\begin{array}{l}\text { Edwards and Ramulu, } \\
2015\end{array}$ & $\begin{array}{c}\text { Ti } 6 \text { Al- } 4 \mathrm{~V} \\
6 \\
\text { plate } \\
\end{array}$ & $\begin{array}{c}\text { W-La } \\
\text { tapered } \\
20(\mathrm{D}) \text { to } 10(\mathrm{~d}) \times 5.9(\mathrm{~L})\end{array}$ & $\begin{array}{c}200-400 \\
50-100 \\
3 \\
\end{array}$ & $\begin{array}{l}- \\
- \\
- \\
\end{array}$ & - $\quad$ Studied material flow within the weld \\
\hline $\begin{array}{l}\text { Edwards and Ramulu, } \\
2015\end{array}$ & $\begin{array}{c}\text { Ti } 6 \mathrm{Al}-4 \mathrm{~V} \\
3,6,9 \text { and } 12 \mathrm{~mm} \\
\text { plate } \\
\end{array}$ & $\begin{array}{c}\text { W-La } \\
\text { tapered } \\
\text { Various } \\
\end{array}$ & $\begin{array}{c}170-300 \\
65-100 \\
- \\
\end{array}$ & $\begin{array}{c}- \\
- \\
300-360(\mathrm{SZ}) \\
\end{array}$ & - $\quad$ Residual stress measurements taken \\
\hline $\begin{array}{l}\text { Sanders et al, } \\
2015\end{array}$ & $\begin{array}{c}\text { Ti } 6 \mathrm{Al}-4 \mathrm{~V} \\
2.54 \\
\text { plate }\end{array}$ & $\begin{array}{l}- \\
- \\
-\end{array}$ & $\begin{array}{c}300 \\
76 \\
- \\
\end{array}$ & $\begin{array}{c}950-1100 \\
900-1000 \\
330-365(\mathrm{SZ})\end{array}$ & $\begin{array}{ll} & \text { PWHT } 774^{\circ} \mathrm{C} \text { for } 45 \mathrm{mins} \\
- & \text { Fracture toughness tests performed. }\end{array}$ \\
\hline $\begin{array}{l}\text { Esmaily et al, } \\
2013\end{array}$ & $\begin{array}{c}\text { Ti } 6 \text { Al- } 4 \mathrm{~V} \\
4 \\
\text { plate }\end{array}$ & $\begin{array}{c}- \\
- \\
3.5(\mathrm{~L}) \\
\end{array}$ & $\begin{array}{c}450-850 \\
65 \\
2 \\
\end{array}$ & $\begin{array}{c}- \\
- \\
370-400 \\
\end{array}$ & - Comparing cooling rates with GTAW \\
\hline $\begin{array}{l}\text { Kitamura et al } \\
2013\end{array}$ & $\begin{array}{c}\text { Ti 6Al-4V } \\
2 \\
\text { plate } \\
\end{array}$ & $\begin{array}{c}\text { WC } \\
\text { straight } \\
6(\text { d) } \times 1.8(\mathrm{~L}) \\
\end{array}$ & $\begin{array}{c}300-1000 \\
25-400 \\
- \\
\end{array}$ & $\begin{array}{l}- \\
- \\
- \\
\end{array}$ & - $\quad$ Measured peak temperatures and cooling rates \\
\hline $\begin{array}{l}\text { Buffa et al, } \\
2012\end{array}$ & $\begin{array}{c}\text { Ti } 6 \mathrm{Al}-4 \mathrm{~V} \\
3 \\
\text { plate } \\
\end{array}$ & $\begin{array}{c}\begin{array}{c}\text { Various } \\
\text { tapered } \\
5(\mathrm{~d}) \times 2.6(\mathrm{~L}) \\
\end{array} \\
\end{array}$ & $\begin{array}{c}300-1000 \\
35 \\
2 \\
\end{array}$ & $\begin{array}{l}- \\
- \\
-\end{array}$ & - $\quad$ Assessed tool life and weld quality \\
\hline $\begin{array}{l}\text { Steuwer et al, } \\
2012\end{array}$ & $\begin{array}{c}\text { Ti } 6 \mathrm{Al}-4 \mathrm{~V} \\
3 \\
\text { plate } \\
\end{array}$ & $\begin{array}{c}\text { W-La } \\
\text { tapered } \\
8(\mathrm{D}) \times 2.9(\mathrm{~L})\end{array}$ & $\begin{array}{c}550 \\
45-165 \\
0.5 \\
\end{array}$ & $\begin{array}{c}1002-1059 \\
- \\
335-365(\mathrm{SZ})\end{array}$ & - $\quad$ Residual stress measurements taken \\
\hline $\begin{array}{l}\text { Davies et al, } \\
2011\end{array}$ & $\begin{array}{c}\text { Ti } 6 \mathrm{Al}-4 \mathrm{~V} \\
6.35 \\
\text { plate } \\
\end{array}$ & $\begin{array}{c}\mathrm{W}-25 \mathrm{Re} \\
\text { tapered }\left(12^{\circ}\right) \\
9(\mathrm{~d})\end{array}$ & $\begin{array}{c}400 \\
60 \\
- \\
\end{array}$ & $\begin{array}{c}- \\
- \\
330-350(\mathrm{SZ})\end{array}$ & - $\quad$ Demonstrated the use of SSFSW \\
\hline
\end{tabular}




\begin{tabular}{|c|c|c|c|c|c|}
\hline Reference & $\begin{array}{l}\text { Alloy } \\
\text { Thickness (mm) } \\
\text { Form }\end{array}$ & $\begin{array}{l}\text { Tool material } \\
\text { Profile (deg.) } \\
\text { Dimensions }(\mathrm{mm}) \\
\end{array}$ & $\begin{array}{l}\text { Rotation (rpm) } \\
\text { Traverse (mm/min) } \\
\text { Tilt (deg.) }\end{array}$ & $\begin{array}{l}\text { Tensile Strength (MPa) } \\
\text { Yield Strength (MPa) } \\
\text { Hardness (Hv) }\end{array}$ & Additional test information \\
\hline $\begin{array}{l}\text { Edwards and Ramulu, } \\
2010\end{array}$ & $\begin{array}{c}\text { Ti } 6 \mathrm{Al}-4 \mathrm{~V} \\
12 \\
\text { plate }\end{array}$ & $\begin{array}{c}- \\
- \\
6(\mathrm{~L})\end{array}$ & $\begin{array}{c}200-400 \\
50-150 \\
-\end{array}$ & $\begin{array}{l}- \\
- \\
- \\
-\end{array}$ & $\begin{array}{l}\text { Temperature surveys performed } \\
\text { Forging loads also monitored }\end{array}$ \\
\hline $\begin{array}{l}\text { Liu et al, } \\
2010\end{array}$ & $\begin{array}{l}\text { Ti } 6 \mathrm{Al}-4 \mathrm{~V} \\
2 \\
\text { plate }\end{array}$ & $\begin{array}{c}\text { W-Re } \\
- \\
-\end{array}$ & $\begin{array}{c}400 \\
25-100 \\
2.5 \\
\end{array}$ & $\begin{array}{c}930-970 \\
- \\
330-360(\mathrm{SZ}) \\
\end{array}$ & \\
\hline $\begin{array}{l}\text { Zhou et al, } \\
2010\end{array}$ & $\begin{array}{c}\text { Ti 6Al-4V } \\
2 \\
\text { plate } \\
\end{array}$ & $\begin{array}{c}\text { W-3Re } \\
\text { tapered } \\
6 \text { (D) to } 4 \text { (d) } \times 1.8(\mathrm{~L})\end{array}$ & $\begin{array}{c}400-600 \\
75 \\
2.5 \\
\end{array}$ & $\begin{array}{r}920-1040 \\
320-350(\mathrm{SZ})\end{array}$ & \\
\hline $\begin{array}{l}\text { Edwards and Ramulu, } \\
2009\end{array}$ & $\begin{array}{c}\text { Ti } 6 \mathrm{Al}-4 \mathrm{~V} \\
3,6,9 \text { and } 12 \mathrm{~mm} \\
\text { plate }\end{array}$ & $\begin{array}{c}\text { W-La } \\
\text { tapered } \\
\text { Various }\end{array}$ & $\begin{array}{c}140-320 \\
40-130 \\
-\end{array}$ & $\begin{array}{c}- \\
- \\
300-350(\mathrm{SZ})\end{array}$ & \\
\hline $\begin{array}{l}\text { Edwards and Ramulu, } \\
2009\end{array}$ & $\begin{array}{c}\text { Ti } 6 \mathrm{Al}-4 \mathrm{~V} \\
5 \\
\text { plate }\end{array}$ & $\begin{array}{c}\text { W-La } \\
\text { tapered } \\
-\end{array}$ & $\begin{array}{c}150-750 \\
50-200 \\
-\end{array}$ & $\begin{array}{l}- \\
- \\
-\end{array}$ & - Demonstrated super plastic forming post FSW \\
\hline $\begin{array}{l}\text { Zhang et al, } \\
2008\end{array}$ & $\begin{array}{l}\text { CP Ti } \\
3 \\
\text { plate }\end{array}$ & $\begin{array}{l}\text { pcBN } \\
\text { tapered } \\
1.7(\mathrm{~L})\end{array}$ & $\begin{array}{c}200 \\
50 \\
-\end{array}$ & $110-210$ (SZ) & Microstructural characterisation \\
\hline $\begin{array}{l}\text { Pasta and Reynolds, } \\
2008\end{array}$ & $\begin{array}{c}\text { Ti } 6 \text { Al- } 4 \mathrm{~V} \\
2 \\
\text { plate } \\
\end{array}$ & $\begin{array}{l}\text { W-25Re } \\
\text { tapered } \\
5 \text { (d) } \\
\end{array}$ & $\begin{array}{l}150 \\
100 \\
- \\
\end{array}$ & $\begin{array}{c}- \\
- \\
330-360(\mathrm{SZ}) \\
\end{array}$ & - $\quad$ Residual stress measurements taken \\
\hline $\begin{array}{l}\text { Zhang et al, } \\
2008\end{array}$ & $\begin{array}{c}\text { Ti 6Al-4V } \\
3 \\
\text { plate }\end{array}$ & $\begin{array}{c}\text { Mo } \\
- \\
-\end{array}$ & $\begin{array}{c}300-600 \\
60 \\
-\end{array}$ & $\begin{array}{c}900-1050 \\
800-950 \\
300-315(\mathrm{SZ})\end{array}$ & \\
\hline
\end{tabular}

L - Length, D - Largest diameter, d- Smallest diameter 
2017-02-24

\section{Alternative friction stir welding pÿtechnology for titanium 6Al 4V propellant tanks within the space industry}

Brassington, W. D. P.

Maney Publishing (T\&F)

pÿWDP Brassington, PA Colegrove. Alternative friction stir welding technology for titanium 6Al 4V propellant tanks within the space industry. Science and Technology of Welding and Joining, 2017, Volume 22, Issue 4, pp300-318

http://dx.doi.org/10.1080/13621718.2016.1236002

Downloaded from Cranfield Library Services E-Repository 